\title{
Oviduct: roles in fertilization and early embryo development
}

\section{Shuai Li and Wipawee Winuthayanon}

School of Molecular Biosciences, College of Veterinary Medicine, Washington State University, Pullman, Washington, USA
Correspondence should be addressed to W Winuthayanon Email

winuthayanonw@vetmed wsu.edu

\begin{abstract}
Animal oviducts and human Fallopian tubes are a part of the female reproductive tract that hosts fertilization and pre-implantation development of the embryo. With an increasing understanding of roles of the oviduct at the cellular and molecular levels, current research signifies the importance of the oviduct on naturally conceived fertilization and pre-implantation embryo development. This review highlights the physiological conditions within the oviduct during fertilization, environmental regulation, oviductal fluid composition and its role in protecting embryos and supplying nutrients. Finally, the review compares different aspects of naturally occurring fertilization and assisted reproductive technology (ART)-achieved fertilization and embryo development, giving insight into potential areas for improvement in this technology.
\end{abstract}
Key Words
- embryo protection
- embryo transport
- estrogen and progesterone
- fallopian tube
- oviductal fluid

\section{Introduction}

Fertilization is a complex process that enables the reproduction and continuation of the species. In mammals, successful fertilization requires that sperm should survive the extremely harsh environment of the female reproductive tract and reach the site of the newly released egg(s) in the oviduct (or Fallopian tube in humans). The oviduct, a part of the female reproductive tract, is a tube-like structure that connects the ovary to the uterus. The oviduct is composed of the following three main regions ordered from the ovary toward the uterus: the infundibulum (fimbria in humans), in which most cells are ciliated epithelial cells; the ampulla, which contains large numbers of ciliated epithelial cells and is the site of fertilization; and the isthmus, which contains a large number of secretory epithelial cells. With these three distinct structures, the oviduct serves as a passage that transports gametes and the embryo as well as provides important structural, environmental and nutritional support for early embryonic development. Unlike the ovary and uterus, which have been extensively studied and relatively well understood, the oviduct is less well understood for its contribution in reproduction. Yet, dysregulation or disruption of oviductal function can result in infertility or life-threatening conditions such as ectopic pregnancy.

This review focuses on the oviductal function in establishing successful pregnancy, with new insights based on recent discoveries. This article first explains the oviductal function before fertilization during sperm and egg transport. Then, it describes oviductal function in fertilization, embryo development, embryo transport and abnormalities of the oviduct that could disrupt these processes. Because assisted reproductive technologies (ARTs), such as in vitro fertilization (IVF) and intracytoplasmic sperm injection (ICSI), can bypass the human Fallopian tubes entirely, this review also outlines the possible adverse outcomes of IVF/ICSI to emphasize

Published by Bioscientifica Ltd 
the importance of the oviduct during fertilization and embryo development.

\section{The path to fertilization}

At intercourse, sperm entering the vagina have to survive a hostile vaginal microenvironment, including strong acidic conditions (Oberst \& Plass 1936), before entering the cervix. The cervical mucus flow flushes out pathogens and removes non-motile sperm (Tung et al. 2015), as recently reviewed in Suarez (2016). The flow naturally selects for healthier sperm to advance to the uterus, where phagocytosis continues to remove weaker sperm. Then, the sperm undergo hyperactivation, a process that is required to complete their physiological change to become competent for fertilizing the egg (reviewed in Tosti \& Menezo 2016). Only hyperactivated sperm generate a strong counter-beating flagellum to overcome the viscoelastic mucus created by oviductal epithelial cells (Suarez et al. 1991, 1992). Details for sperm transport through the female reproductive tract are discussed in the following sections.

\section{Oviduct guides sperm to the fertilization site}

There are three potential mechanisms that guide the sperm through the oviduct, including rheotaxis, thermotaxis and chemotaxis.

\section{Rheotaxis}

Once sperm enter the oviduct, they will have direct contact with the oviductal fluid, which is generated by the transudate fluid from the systematic circulation and the secretory epithelial cells of the oviduct (Leese 1988). The fluid current is generated by ciliated epithelial cells and tubal contraction, which provides significant support to transport eggs and embryos. For sperm, the contact with epithelia and fluid to cause fertilization requires morphological changes to overcome this upcoming obstacle. One of the tubal current functions is to conduct a rheotaxis mechanism to guide the sperm to the site of fertilization (Fig. 1) (Miki \& Clapham 2013). Rheotaxis is a mechanism whereby capacitated sperm can move against the direction of the current.

Soon after the sperm enter the isthmic region of the oviduct, the sperm heads attach to the oviductal epithelial cells. The studies using scanning electron micrographs of

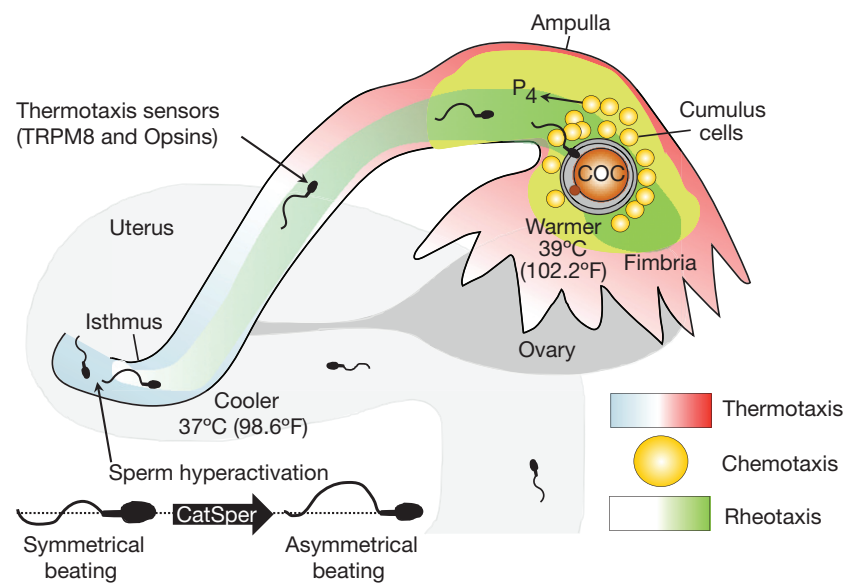

Figure 1

Oviduct-guided fertilization. The oviduct regulates fertilization through sperm guidance and sperm hyperactivation. The sperm guidance is achieved through rheotaxis, thermotaxis and chemotaxis. Rheotaxis is created by tubal fluid, which generates a current flow from the ampulla toward the isthmus of the oviduct. Sperm swim against this current based on the physical rotation of the flagella upon CatSper (Cation channel of Sperm) activation. Thermotaxis is mediated through a $\mathrm{Ca}^{2+-s e n s i n g}$ transient receptor potential channel (TRPM8) and G protein-coupled receptor (opsins). This thermal sensibility of human sperm can detect a difference of $0.006^{\circ} \mathrm{C}$ (Bahat et al. 2012). Temperatures depicted $\left(37^{\circ} \mathrm{C}\right.$ vs $39^{\circ} \mathrm{C}$ ) are from the finding in rabbits (Bahat et al. 2003). Chemotaxis is driven through progesterone $\left(\mathrm{P}_{4}\right)$ released from the cumulus cells and through small cytokines found in the follicular fluid. Together, these processes provide guidance for sperm to swim toward the eggs and be competent for fertilization. COC, cumulus-oocyte complex.

bovine sperm illustrate the physical interaction between the sperm head and cilia on the apical surface of oviductal epithelial cells (Pollard et al. 1991). Interaction between oviductal epithelial cells and sperm has also been observed in rabbit (Smith \& Nothnick 1997), horse (Dobrinski et al. 1997) and human (Morales et al. 1996). In mice, the sperm attach to and detach from the oviductal epithelial cells several times before reaching the ampulla (Chang \& Suarez 2012). Additionally, recent findings indicate that there are dynamic differences between the physical interactions between the sperm and the oviductal epithelial of the ampullary and isthmic regions (Ardon et al. 2016). Ultimately, the attachment of the sperm and the epithelial cells create a deposition or a reservoir of sperm within the oviduct.

Sperm-oviductal epithelial interaction causes the modification of sperm surface proteins and subsequently induces the hyperactivation of the sperm by activating the CatSper (Cation channels of Sperm) on the flagella (Ren et al. 2001, Quill et al. 2003, Chung et al. 2011, Miki \& Clapham 2013). Upon CatSper activation, a large $\mathrm{Ca}^{2+}$ ion influx in the sperm flagella is triggered, subsequently http://joe.endocrinology-journals.org DOI: $10.1530 / J O E-16-0302$
๑ 2017 Society for Endocrinology Printed in Great Britain
Published by Bioscientifica Ltd 
altering the beating pattern from symmetrical to aggressive asymmetrical propulsion (Fig. 1). Asymmetrical beating of the flagella produces greater amplitude of force and subsequently aids its speed toward the end of the journey. Studies have demonstrated that CatSper activation and the physical rotation of the sperm flagella are the mechanisms behind rheotaxis (Miki \& Clapham 2013). The sperm from male mice lacking CatSper cannot be hyperactivated, and the males are sterile (Ren et al. 2001). Therefore, the activation of the CatSper channel and the downstream physiological changes are required for sperm to become fertile.

\section{Thermotaxis}

In addition to the CatSper channel, a $\mathrm{Ca}^{2+}$-sensing transient receptor potential channel (TRPM8) (De Blas et al. 2009) and a G protein-coupled receptor well known for its role in photon sensing in the retina (opsins) (PerezCerezales et al. 2015) are also present on the sperm. Combined with other recent studies on human sperm, it is possible that sperm have the ability to detect shallow temperature differences of less than one-hundredth of a degree (in Celsius) (Bahat et al. 2012). Thermosensing ability allows sperm to be directionally guided according to the oviduct temperature gradient, as previously observed in rabbit, mouse, pig, cow and human (Hunter et al. 2000, Bahat et al. 2003, 2005, Hunter 2012). Despite the studies conducted concerning the thermosensing channels and the temperature difference in the oviduct, some evidence suggests that the temperature gradient in the oviduct serves to influence gene expression and protein modification of the egg and embryo (Grinsted et al. 1985, Ye et al. 2007); however, thermotaxis may play a minor role in sperm guidance compared with rheotaxis.

\section{Chemotaxis}

Chemotaxis of sperm has been studied in different species and is most well known in sea urchins via resact, a peptide released from the egg (Ward et al. 1985). In Xenopus, egg jelly also produces allurin as chemotaxis for sperm attraction (Olson \& Chandler 1999, Olson et al. 2001). In humans, freshly released cumulus-oocyte complexes (COCs) can secrete progesterone $\left(\mathrm{P}_{4}\right)$ as a chemoattractant for sperm (Teves et al. 2006, Oren-Benaroya et al. 2008). Chemokine receptors - CCR1, CCR5 and CCR6 - have been identified on human sperm (Isobe et al. 2002, Caballero-Campo et al. 2014). CCL20 ligands found in the follicular fluid can bind to CCR6 and alter sperm directional movement (Caballero-Campo et al. 2014). The merging of follicular fluid and the oviductal fluid after ovulation may provide sufficient chemoattractants to ensure the arrival of sperm at the ampulla.

Atrial natriuretic peptide (ANP) and its precursor A (NPPA) are found in pig, mouse, rat and rabbit oviducts (Kim et al. 1997, Zhang et al. 2006, Bian et al. 2012). ANP receptor (NPR1), however, is expressed on the sperm. Upon ANP and NPR1 binding, ANP activates the cyclic GMPdependent protein kinase pathway (PKG) and induces acrosome reactions in pig, cow and human sperm (Zamir et al. 1995, Rotem et al. 1998, Zhang et al. 2006). This reaction might provide additional evidence regarding the role of ANP as a human sperm chemoattractant (Zamir et al. 1993, Anderson et al. 1995).

Anandamide (AEA), a phospholipid signaling molecule, acts through cannabinoid receptors 1 and 2 (encoded by Cnr1 and Cnr2 genes) and was previously identified to regulate neurological signaling and memory (Subbanna et al. 2013, Basavarajappa et al. 2014). AEA has been found in oviductal fluid, whereas CNR1 is present on the sperm (Aquila et al. 2010, Gervasi et al. 2013). AEA regulates sperm metabolism through insulin secretion (Aquila et al. 2009), implying the possibility that AEA from the oviduct externally facilitates the metabolism of sperm. Recently published studies suggested that AEA in the oviduct activates CNR2 and transient receptor potential vanilloid 1 (TRPV1) to induce $\mathrm{Ca}^{2+}$ influx into the sperm, which become hyperactivated and are released from oviductal epithelia (Gervasi et al. 2011, 2016, Osycka-Salut et al. 2012, Amoako et al. 2013).

Overall, the oviduct guides sperm toward the fertilization site through various comprehensive mechanisms. Most importantly, the oviduct facilitates the hyperactivation of sperm to become fertile.

\section{Egg entering the oviduct}

Unlike sperm, eggs are released from the ovary during ovulation and enter the infundibulum (or fimbria). The cumulus cells surrounding the egg form the cumulusoocyte complex or COC. Once inside the oviduct, the cumulus cells serve as a nutrient support for the egg. The cumulus cells use glucose for their own energy production (Sutton et al. 2003) and also produce energy sources (pyruvate and cysteine) that are needed for the cellular functions of the eggs (Tanghe et al. 2002, Sutton-McDowall et al. 2010). Cumulus cells also bridge

Published by Bioscientifica Ltd 
the communication between the environment and the egg through gap junctions (Simon et al. 1997, Li et al. 2007, Huang \& Wells 2010).

The initial attachment of the egg to the oviduct epithelia is accomplished through COC-oviduct epithelia interaction. The filaments of the extracellular matrix from cumulus cells adhere to the glycocalyx at the entrance of the ciliary crowns at the epithelial cells of the infundibulum (Lam et al. 2000). Then, the COC is drawn into the oviduct and is ready for fertilization.

\section{Other aspects of oviduct-guided fertilization}

Sperm orient themselves by reacting to the oviduct environment to continue along the path of fertilization. The oviduct also reacts to the presence of the sperm and optimizes the microenvironment within the oviductal lumen by regulating fluid viscosity, oviductal muscular contraction and by promoting sperm-egg recognition.

\section{Oviductal fluid}

Sperm is bathed in oviductal fluid to advance toward the site of fertilization. The oviductal fluid is generated from secretory cells of the oviduct and is regulated by estrogen $\left(\mathrm{E}_{2}\right)$ and other hormones (discussed in detail in a later section). The oviductal protein concentration is the lowest at ovulation and highest around menstruation (Lippes et al. 1981). Changes in protein concentration and its content can alter fluid viscosity, hence influencing the flow rate of the fluid. Oviductal epithelial cells sense the change of fluid viscosity by transient receptor potential vanilloid 4 (TRPV4) channel (Andrade et al. 2005, Teilmann et al. 2005, Lorenzo et al. 2008). TRPV4 detects phospholipase in the oviductal fluid and regulates ciliary beat frequency $(\mathrm{CBF})$ to enhance the fluid movement when it is too viscose, as observed in the respiratory tract. The oviduct can also sense the presence of sperm and adjust the protein content by increasing heat shock protein 70 (HSP70) and antioxidants in the oviductal fluid, possibly to help reduce sperm stress (Georgiou et al. 2005).

\section{Smooth muscle contraction}

The smooth muscle contraction in the oviduct is regulated by prostaglandins (PGs) through prostanoid receptors, which are modulated by $\mathrm{E}_{2}$ (Spilman \& Harper 1975, Ball et al. 2013, Huang et al. 2015). In humans, the oviductal PGs are mainly PGE and PGF produced by epithelial cells (Lindblom et al. 1983). $\mathrm{PGE}_{2}$ and $\mathrm{PGF}_{2 \alpha}$ increase muscle contraction, whereas $\mathrm{PGE}_{1}$ decreases muscle contraction (Wanggren et al. 2008). Evidence indicates that the contraction is possibly regulated by both $\mathrm{E}_{2}$ and $\mathrm{P}_{4}$, as estrogen and progesterone receptors (ESR and PGR) are expressed in the interstitial Cajallike cells in the muscle cell layer of the oviduct (Cretoiu et al. 2009). The function of the muscle contraction is generally recognized to be for sperm transport purposes (Overstreet \& Cooper 1978a). Suarez and coworkers suggested that the muscle contraction mainly helps the sperm to pass through the cervix, rather than acting as a rapid transport for sperm to reach the fertilization site (Suarez \& Pacey 2006). This idea is strongly supported by experiments in rabbits, in which the sperm that reached the end of the oviduct within a few minutes were damaged (Overstreet \& Cooper 1978a,b).

\section{Fertilization}

Recent studies demonstrated that heat shock proteins are involved with sperm-egg recognition. Heat shock protein member A2 (HSPA2) is present in the human spermatozoa and binds with arylsulfatase A (ARSA) and sperm adhesion molecule 1 (SPAM1) (Redgrove et al. 2012, 2013, Bromfield et al. 2016). Both ARSA and SPAM1 are detected in the rabbit and mouse oviduct (Vitaioli et al. 1996, Griffiths et al. 2008). HSPA2 can also bind with angiotensin-converting enzyme (ACE) and protein disulfide isomerase A6 (PDIA6) to form a complex, and then engage in sperm-zona recognition. Interestingly, oxidative stress of sperm can significantly reduce the binding ability of the ARSA/SPAM1/HSPA2 complex to the zona pellucida (Bromfield et al. 2015).

Soon after the egg and sperm convene at the ampulla, fertilization occurs. With the penetration of the sperm into the egg, ovastacin is released from the egg's cortical granules and cleaves the zona pellucida 2 protein (ZP2) (Burkart et al. 2012), leading to zona hardening and preventing polyspermy. In a recent study, ZP2 peptidetreated beads, deployed in the mouse female reproductive tract, act as a decoy to attract sperm and form binding, resulting in female infertility (Avella et al. 2016). These ZP2 peptide beads efficiently provide a contraceptive mechanism without any pathological defect in the female reproductive tract. Another newly discovered sperm-egg interaction is that of Izumo1 and Juno. Izumo1 is present on the sperm and interacts with the Juno receptor on the egg, causing a rapid shedding of Juno to prevent

Published by Bioscientifica Ltd. 
polyspermy (Bianchi et al. 2014). Juno is a species-specific protein and may contribute to the prevention of cross species sperm-egg recognition (Han et al. 2016).

After sperm-egg recognition, the gametes fuse and the pronuclei form. This event leads to embryogenesis, and the next chapter of development begins. Embryogenesis is a very early stage of the development in which the embryo undergoes a few cellular divisions before entering the uterus. It usually takes 3-4 days for human and mouse embryos to develop into the 8-cell (human) or 16-cell (mouse) stage in the oviduct. Those early cell divisions do not increase cell size but rather equally allocate the cytoplasm from the original zygote (Pelton et al. 1998). The embryo is transported from the site of fertilization toward the end of the oviduct during the early cleavage stage. At the end of the oviduct, embryos prepare to enter the uterus at the morula and blastocyst stages. The simultaneous embryo development and transport in the oviduct is an inseparable mechanism under normal physiological conditions.

\section{Oviductal influence on embryo development}

The pre-implantation embryo is housed inside the oviduct, exposed to and surrounded by oviductal secretory fluid and in contact with the oviductal epithelial cells. The microenvironment within the oviduct provides a stable temperature, optimal $\mathrm{pH}$ and dynamic fluid secretions to support embryo development.

Before fertilization, the oviductal fluid serves in the following three major functions: gamete protection, sperm guidance and egg guidance (Ballester et al. 2014, Kumaresan et al. 2014). After fertilization, the oviduct assists the development of pre-implantation embryos by producing the factors required for embryo cleavage (discussed in following sections). This phenomenon was first described in the sheep model where the oviductal epithelial cells were cultured with the embryos (Gandolfi \& Moor 1987). Gandolfi and coworkers found that the blastocyst cleavage rate was at $80 \%$ when the embryos were cultured with oviductal epithelial cells, in comparison to a $33 \%$ cleavage rate when cultured with fibroblast cells. This finding indicates that the presence of oviductal epithelial cells, and not just any type of somatic cell, is crucial for blastocyst development. The improvement of embryo development after culturing with oviductal epithelial cells or explanted oviduct has also been demonstrated in several species, including mouse (Sakkas \& Trounson 1990), pig (White et al. 1989), cattle (Eyestone \& First 1989) and human (Yeung et al. 1992). These findings indicate that the oviduct epithelia and the oviductal fluid provide the pre-implantation embryos an ideal physiological and biochemical environment to sustain development.

To determine the possible factors secreted from the oviductal epithelial cells that support and promote embryo development, we have outlined the fluid constituents during the early stage of pregnancy. Oviductal fluid is generated by two compositions: (1) the transudation of the systemic circulation and (2) the active biosynthesis from the secretory epithelial cells of the oviduct (Leese 1988). The fluid is composed of albumin, transferrin, glycoproteins, galactose, immunoglobin, glucose, pyruvate, amino acid, lactate, cytokines, many growth factors and a monitored gas composition (Beier 1974, Leese 1988). The functions of these factors in the oviduct are discussed in the following sections.

\section{Oviductal fluid: influence on embryo nutrient and growth}

\section{Nutrients}

Early embryos usually stay in the oviduct for 3-4 days (Croxatto 2002). During this time, the fertilized embryos transition from oxidative metabolism to glycolic metabolism (Folmes \& Terzic 2014). This transition is accompanied by (1) different nutrient compositions as the embryo travels through the oviduct, (2) maturation of the mitochondria to enable the embryo to establish its own metabolism and (3) a change in oxygen tension parallel to this shift in metabolism (Gardner et al. 1996, Absalon-Medina et al. 2014).

After the cumulus cells fall off in post-fertilization, the pre-implantation embryos use oxidative metabolism to acquire energy, mostly from pyruvate and lactate as the main sources of energy (Gardner \& Leese 1990, Dumollard et al. 2007a,b, Absalon-Medina et al. 2014). Pyruvate, lactate, lipids and amino acids are present in the oviductal fluid, and the levels of these nutrients fluctuate through the estrous cycle in mice, rabbits, pigs and humans (Nieder \& Corder 1982, 1983, Nichol et al. 1992, Leese et al. 1993, Tay et al. 1997). The carboxylic acids are processed through immature mitochondria (characterized by the short and less formed cristae, shown in Fig. 2A) (Motta et al. 2000, Trimarchi et al. 2000, Dumollard et al. 2007a). Several studies in pigs and cattle showed that fatty acids (in a form of acyl-coA) are used as an energy source for the embryo (Sturmey et al. 2009,

Published by Bioscientifica Ltd 


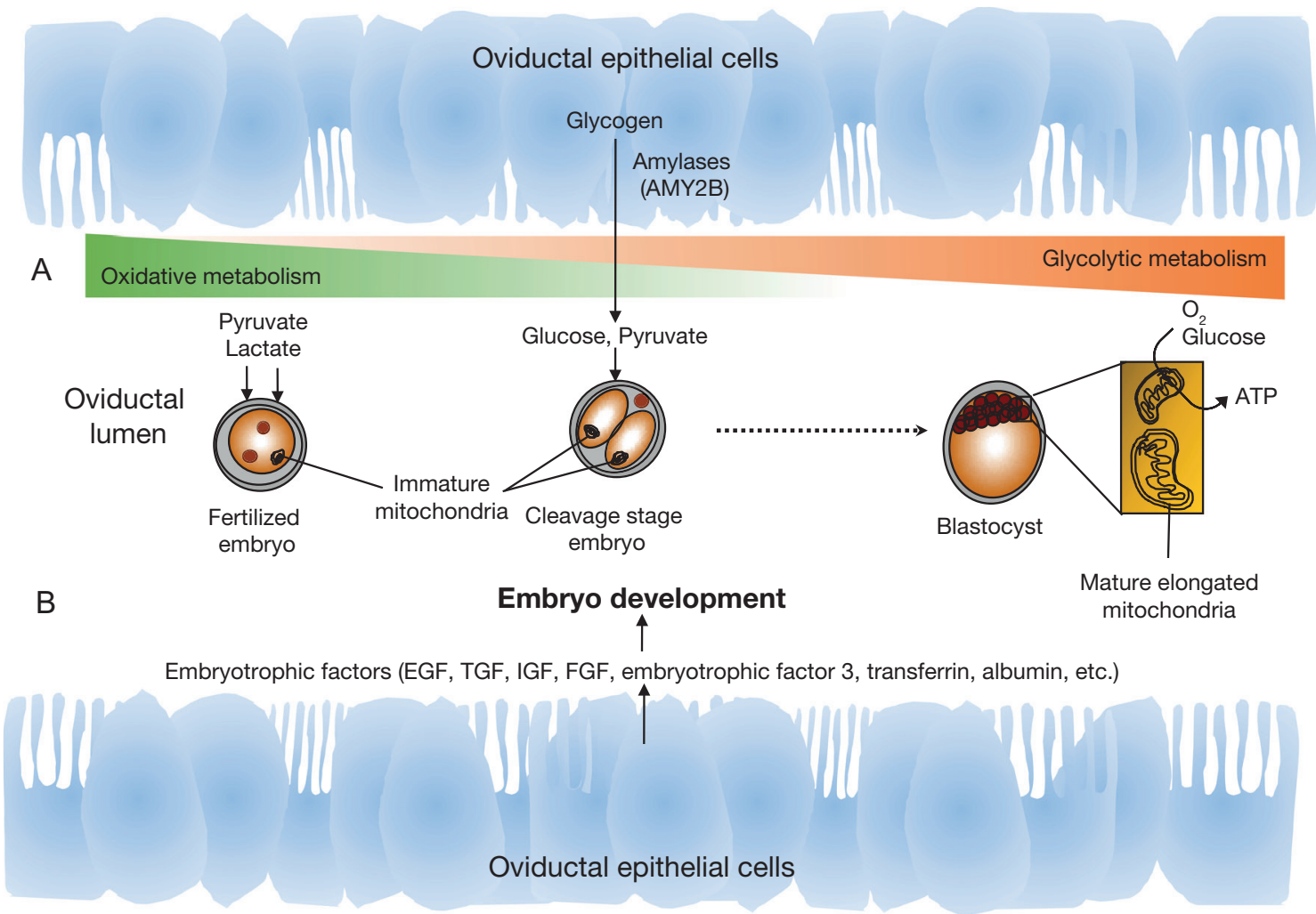

\section{Figure 2}

The influence of the oviduct on embryo development. (A) The main energy supply for the embryos is pyruvate and lactate. During the very early stage of embryo development, pyruvate and lactate are provided by the oviductal fluid as energy sources for oxidative metabolism. The oviduct can also supply the glycogen as an energy source for the embryos during the cleavage stage. Amylase (AMY2B) is produced within the oviductal epithelial cells and converts glycogen to sugar. At this stage, the mitochondria of the embryos are immature and do not function. During morula and blastocyst stages, the mitochondria are fully mature and can use oxygen and glucose to produce their own energy via glycolysis as they leave the oviduct. (B) At the same time, oviductal epithelial cells provide embryotrophic factors, such as growth factors, to promote cleavage and embryo development. EGF, epidermal growth factor; FGF, fibroblast growth factor; IGF, insulin-like growth factor; TGF, transforming growth factor.

Sutton-McDowall et al. 2012). Acyl-CoA diffuses through the mitochondrial membrane in the presence of carnitine (as a cofactor) through carnitine palmitoyl transferase $1 \mathrm{~B}$ (СРT1B) and is used for $\beta$-oxidation, resulting in the production of acetyl-CoA (Sutton-McDowall et al. 2012).

As embryos continue developing, glycolytic metabolism slowly takes over as the mitochondria become mature. However, in human, the metabolic switch is not complete until the blastocyst stage (Sathananthan \& Trounson 2000). This glycolytic metabolism requires supplies of glucose and simple sugars. Glycogen granules are present in the ampulla and isthmic secretory cells of the oviduct in monkey and human (Odor et al. 1983, Schultka \& Cech 1989). In pigs, the glycogen level increases after ovulation (Lindenbaum et al. 1983, Gregoraszczuk et al. 2000). This evidence suggests that oviduct secretion prepares embryo metabolism transit during the pre-implantation stage. Additionally, enzyme amylase (AMY2B) plays a major role in converting glycogen into sugar. Several studies indicated that there is an upregulation of AMY2B in the human Fallopian tube (Mc et al. 1958, Hochberg 1974, Hayashi et al. 1986, Groot et al. 1990, Marquez et al. 2005). Therefore, it is likely that the compact polysaccharide can be converted into a simple sugar by AMY2B in the oviduct, and these simple sugar molecules can be used in cellular metabolism by both the oviduct and the cleaving embryo.

When human embryos develop into blastomeres, mitochondria are equally divided into each of the cells and are elongated and matured (Fig. 2A). The mature mitochondria can now use oxygen and glucose in glycolysis to provide ATP for further embryo development (Sathananthan \& Trounson 2000). In mice, this is evident with the timing of embryo oxygen consumption, which peaks at the blastocyst stage (Leese 2012).
๑) 2017 Society for Endocrinology Printed in Great Britain 
In addition to energy substrates, $\mathrm{CO}_{2}$ also serves as a carbon source for RNA synthesis (Quinn \& Wales 1974, Pike et al. 1975). In mouse and rabbit, $\mathrm{CO}_{2}$ fixation has been demonstrated in early developing embryos (Quinn \& Wales 1974, Pike et al. 1975). The level of $\mathrm{CO}_{2}$ is inversely proportional the $\mathrm{HCO}_{3}{ }^{-}$concentration, which is modulated by the carbonic anhydrase (CA) enzyme expressed in the oviductal epithelial cells (Lutwak-Mann 1955 , Ge \& Spicer 1988) as well as a $\mathrm{Cl}-/ \mathrm{HCO}_{3}-$ exchanger (solute carrier family 26) expressed in pre-implantation embryos (Lu et al. 2016). The $\mathrm{HCO}_{3}{ }^{-}$level in the oviduct is relatively high compared with other tissues (Vishwakarma 1962, Maas et al. 1977), and it has been previously shown that $\mathrm{HCO}_{3}{ }^{-}$is indispensable for the cleavage of pre-implantation embryos (Kane 1975). These studies indicate that a balance of $\mathrm{CO}_{2}$ and $\mathrm{HCO}_{3}$ - concentration needs to be fine-tuned not only for optimal $\mathrm{pH}$ conditions but also for RNA synthesis and the normal cleavage of the pre-implantation embryo development.

\section{Growth factors}

Embryotrophic factor-3 from human oviductal cells plays a significant role in enhancing pre-implantation embryo development by promoting proliferation and inhibiting apoptosis (Xu et al. 2004). Epidermal growth factor (EGF) (Adachi et al. 1995), transforming growth factor (TGF) (Chegini et al. 1994), insulin-like growth factor (IGF) (Carlsson et al. 1993, Pfeifer \& Chegini 1994, Daliri et al. 1999) and fibroblast growth factor (FGF) are all detected in human Fallopian tissues (Fig. 2B). Mouse embryos cultured with EGF, TGF and IGF have an increased number of blastocyst development from 2-cell embryos (Paria \& Dey 1990). The co-cultured 2-cell stage embryo and the Fallopian tube epithelial cells significantly increase the cleavage rate and enhance blastocyst development (Takeuchi et al. 1992). However, in similar co-culture conditions, inhibition of EGF and TGF will attenuate the development of embryo from the cleavage stage to blastocyst. IGF receptor is also detected in 8-cell stage buffalo embryos (Daliri et al. 1999). This suggests that embryotrophic factors, including growth factors in the tubal fluid, can have a direct positive impact on cleavage stage embryo development.

In addition to the growth factors listed previously, hormone-like lipids such as prostaglandins also promote embryo development. In mice, the oviduct produces 10 times more prostaglandin $\mathrm{I}_{2}\left(\mathrm{PGI}_{2}\right)$ at day 2 than day 4 after coitus (Huang et al. 2004). The spiked production of $\mathrm{PGI}_{2}$ is timed with the early cleavage stages of the embryo, and then the production drops around the time embryos hatch in the uterus. This finding suggests that $\mathrm{PGI}_{2}$ potentially plays a role in early embryo development. Additionally, several studies demonstrated that addition of transferrin, albumin and selenium can improve bovine and goat embryonic development (Hammami et al. 2013, Wydooghe et al. 2014, Xie et al. 2015, Guimaraes et al. 2016). These findings suggest that the presence of growth factors in the tubal fluid may play an important role in promoting and enhancing embryogenesis.

\section{Oviductal fluid: protection against embryo stress}

Tubal fluid protects gametes from environmental stress to ensure embryo quality and pregnancy outcome. After the shedding of the cumulus cells, the embryo depends on tubal fluid and internal antioxidant activities to gain protection against reactive oxygen species (ROS)-induced stress (Fig. 3). Two major systems are involved in this process: non-enzymatic and enzymatic antioxidants (reviewed in Guerin et al. 2001).

Reduced glutathione (GSH), taurine, hypotaurine and cysteamine $(\mathrm{CSH})$ are the main non-enzymatic antioxidants in the oocytes and embryos (Guerin et al. 2001). GSH reduces ROS level in the oocytes and increases the hatching rate of mouse blastocysts when added into the culture medium (Gardiner \& Reed 1994). Moreover, considerable amounts of GSH are detected in the mouse oviduct and uterine flushing (Gardiner et al. 1998). CSH is

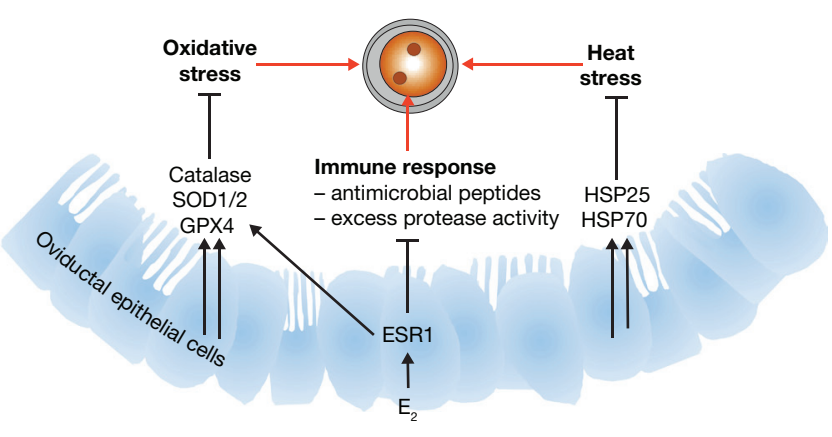

Figure 3

Oviduct-mediated embryo protection against stress and immune responses. Oviductal epithelial cells produce heat shock protein family (HSP25 and HSP70) to handle heat stress. Oviductal fluid also contains catalase, superoxide dismutases (SOD1/2) and glutathione peroxidase (GPX4) to reduce stress of the embryos from reactive oxygen species. In addition to stress, the oviduct also protects the embryos against their own immune system, partly through the $E_{2} / E S R 1$ signaling, by inhibiting the production of antimicrobial peptides and excess protease activity. ESR1, estrogen receptor $\alpha$.

Published by Bioscientifica Ltd. 
present in the secretions of the female reproductive tract (Guyader-Joly et al. 1998) and is proposed to act through the hydroxyl radical $\left(\mathrm{OH}^{\bullet}\right)$ scavenging pathway (Guerin et al. 2001). The $\mathrm{OH}^{\bullet}$ scavenging pathway may also covert $\mathrm{CSH}$ into hypotaurine, a sulfinic acid neutralizing $\mathrm{OH}^{\bullet}$ activity, and generate taurine as a byproduct (Guerin \& Menezo 1995). Both hypotaurine and taurine are present at high levels in the embryo environment and are produced by the oviduct epithelial cells of cow, sheep, goat and rabbit (Guerin et al. 1995, Guerin \& Menezo 1995). In addition, albumin and transferrin are highly abundant in the oviductal fluid. Transferrin acts as a metal chelator to prevent the formation of $\mathrm{OH}^{\bullet}$ from $\mathrm{Fe}^{2+}$ ions (Nasr-Esfahani \& Johnson 1992, Guerin et al. 2001), whereas albumin is shown to prevent lipid peroxidation in the sperm (Alvarez \& Storey 1983), suggesting that both transferrin and albumin may provide indirect protection for the embryos against oxidative stress.

In the enzymatic pathway, catalase, superoxide dismutases (SODs) and glutathione peroxidases (GPXs) are the major enzymes involved in embryo protection (Guerin et al. 2001). Catalase is one of the enzymes that converts ROS into $\mathrm{H}_{2} \mathrm{O}$ and $\mathrm{O}_{2}$ (Harvey et al. 1995). Similarly, SOD1 and SOD2 bind to ROS byproducts and turn the byproducts into $\mathrm{O}_{2}$ and hydrogen peroxide (El Mouatassim et al. 2000, Jang et al. 2010). Catalases, SOD1 and SOD2 are found in the oviduct of mice, cows and humans. Glutathione also plays a similar role in embryonic development and protection (Salmen et al. 2005, Hansen \& Harris 2015). GPX4 is well known for its function in suppressing cell death and reduction in hydrogen peroxide (Imai et al. 1996, Agbor et al. 2014). Increase in $\mathrm{E}_{2}$ induces the GPX4 production in bovine oviduct (Lapointe et al. 2005). This evidence indicates that $\mathrm{E}_{2}$ and the oxidative stress preventing enzymes act in concert to protect the embryos against ROS exposure.

In addition to oxidative stress, embryos also encounter physical stress from the environment. The 1to 2-cell stage mouse embryo expresses HSP70, which is regulated by heat shock factors (HSFs) (Christians et al. 1995, 1997). HSP70 family proteins play an important role in protecting the cell from heat stress by ensuring correct protein folding. Interestingly, the oviduct expresses HSF25 and 70 (Fig. 3), which can potentially provide heat stress protection at the molecular level to ensure correct protein folding in the newly fertilized embryo (Mariani et al. 2000, 2003). Mice lacking $H s f s$ had significant increases in cell death when the embryos experienced heat stress for $2 \mathrm{~h}$ (Le Masson \& Christians 2011). A study in water buffalo indicated that when the embryos are exposed to heat stress for a prolonged period of time $(24 \mathrm{~h})$, the heat also decreases embryo cell numbers (Ashraf et al. 2014). These studies suggest that there is a tolerable limit of heat stress that the embryo can handle.

\section{Estrogen-mediated embryo protection against immune system}

$\mathrm{E}_{2}$ and its nuclear receptors (estrogen receptors) play a major role in the reproductive system, from regulating the hormonal cycle, ovulation and sexual behavior to cancer development (Couse \& Korach 1999). Numbers of studies demonstrated that $\mathrm{E}_{2}$ is required for immunoprotection in the female reproductive tract, including the vagina and uterus (Wira et al. 2005, Haddad \& Wira 2014). However, the actions of $E_{2}$ in regulating the immune functions in the oviduct are unclear. Recently, a study indicated another important property that $\mathrm{E}_{2}$ possesses-embryo protection. $\mathrm{E}_{2}$ acts through estrogen receptor $\alpha$ (encoded by Esr1 gene) in the oviductal epithelial cells, which protects embryos from the attack of the maternal immune system. Loss of ESR1 in the oviductal epithelial cells in female mice results in excess protease activity and increased expression of antimicrobial peptides such as defensins. These changes, due to a lack of ESR1 in the oviduct, dampen the plasma membrane integrity of the embryos and ultimately cause embryonic death before the 2-cell stage (Winuthayanon et al. 2015). The study demonstrated that the epithelial ESR1 is required to suppress innate immune systems (Fig. 3) by changing gene expression related to inflammation responses in the oviduct during day 1 and 2 of pregnancy. This result suggests that without $\mathrm{E}_{2}$ signals through ESR1 on the oviductal epithelial cells, newly fertilized embryos will not be able to overcome the mother's immune system. These findings reveal another infertility scenario that previously has not been demonstrated, in which the disruption of $\mathrm{E}_{2}$ signaling or ESR1 action in the Fallopian tube can cause infertility.

\section{Gas in the oviduct}

Little is known about the gas composition in the oviduct or the oviductal fluid. Compared with the $20 \%$ oxygen level in the atmosphere, the concentration of oxygen in the oviduct of monkeys, hamsters and rabbits is between 2\% and 8\% (Mastroianni \& Jones 1965,

Published by Bioscientifica Ltd. 
Yedwab et al. 1976, Fischer \& Bavister 1993). The relatively low oxygen concentration in mammalian oviducts could result in minimal ROS levels and protect embryos from stress, as high concentrations of oxygen can lead to an increase in ROS and oxidative stress (Catt \& Henman 2000).

Dysregulation of $\mathrm{H}_{2} \mathrm{~S}$ gas in the Fallopian tubes has been linked to impaired embryo transport in humans. $\mathrm{H}_{2} \mathrm{~S}$ is abundant in the Fallopian tube epithelial cells and synthesized intrinsically through the cell cytoplasm. This signaling pathway is upregulated during pregnancy and is mainly responsible for spontaneous oviduct muscle contraction, which provides a positive factor to the embryo movement toward the uterus (Ning et al. 2014). Nitric oxide has been identified in the Fallopian tube; it mediates tubal muscle contraction, with possible roles in the regulation of sperm motility (Ekerhovd et al. 1997, Kobayashi et al. 2016). Dimethylarginine dimethylaminohydrolase 2 (DDAH2), an enzyme regulating nitric oxide synthesis, is also expressed in the oviduct in the presence of egg and embryo (Georgiou et al. 2005). Therefore, $\mathrm{H}_{2} \mathrm{~S}$ and nitric oxide could contribute to the regulation of tubal contraction during fertilization and embryo transport.

\section{Embryo transport}

It is necessary to mention embryo transport, as embryo development and transport occur simultaneously. Embryo transport from the oviduct to the uterus takes approximately 1-10 days, depending on the species (reviewed in Croxatto 2002). In mammals, unfertilized eggs and embryos are transported to the uterus at different rates. In horses, only embryos are transported to the uterus, whereas the unfertilized eggs are retained in the oviduct (Betteridge \& Mitchell 1974, Flood et al. 1979, Freeman et al. 1992). Several studies indicated that horse embryos produced prostaglandin $\mathrm{E}_{2}\left(\mathrm{PGE}_{2}\right)$, which mediates an acceleration of the transit to the uterus (Weber et al. 1991a,b). In rats and hamsters, fertilized eggs reach the uterus at higher rates compared with the unfertilized eggs (Villalon et al. 1982, Ortiz et al. 1986). These findings illustrate that embryo transport is an interactive process between the embryos and the oviduct. Here, the three major elements regulating embryo transport are listed: the beating of ciliated epithelia, tubal fluid flow and tubal muscle contraction (Fig. 4).

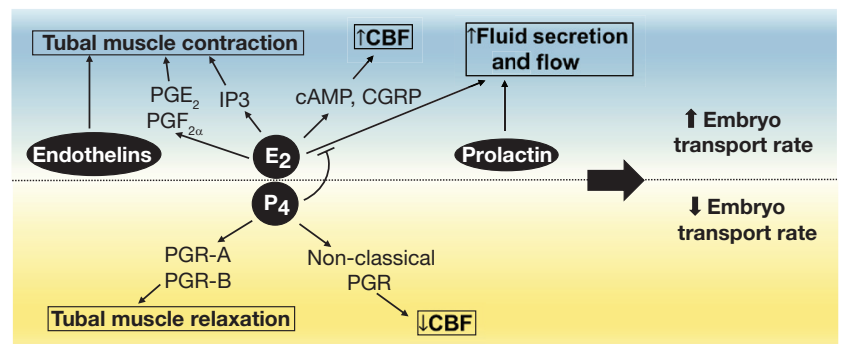

Figure 4

Roles of the oviduct during embryo transport. Embryo transport is composed of tubal muscle contraction and the motility of ciliated epithelial cells. Estrogen $\left(E_{2}\right)$ generally increases the tubal muscle contraction, tubal fluid secretion, and ciliary beat frequency (CBF), which accelerate the embryo transport rate. Opposite to $E_{2}$, progesterone $\left(P_{4}\right)$ causes muscle relaxation and decreases $\mathrm{CBF}$ to reduce the embryo transport rate. In addition, $\mathrm{P}_{4}$ also inhibits $\mathrm{E}_{2}$-induced tubal fluid production. Prostaglandins (PGs) can be produced in the oviductal epithelial cells or induced by $E_{2}$ treatment. $\mathrm{PGE}_{2}$ and $\mathrm{PGF}_{2 \alpha}$ stimulate muscle contraction in both human and bovine oviducts. Endothelin 1 and 2 are expressed and contribute to the oviduct contraction. IP3, inositol triphosphate; $\mathrm{PGE}_{2}$, prostaglandin $\mathrm{E}_{2} ; \mathrm{PGF}_{2 \alpha}$ prostaglandin $\mathrm{F}_{2} ; \mathrm{PGR}$, progesterone receptor.

\section{Ciliary beating}

Ciliated epithelial cells have a multiciliated structure on the apical plasma membrane. The beating of the cilia generates the movement of the fluid in the oviduct, which promotes the movement of the embryo.

$\mathrm{P}_{4}$ and $\mathrm{E}_{2}$ are the key players in regulating ciliary beat frequency $(\mathrm{CBF}) . \mathrm{P}_{4}$ reduces $\mathrm{CBF}$ through classical progesterone receptors (PGRs) expressed on the ciliated epithelial cells in a dosage-dependent manner in humans and mice (Mahmood et al. 1998, Bylander et al. 2010, 2013). A non-classical PGR is expressed in the lower part of the cilia stalk in mouse oviducts (Teilmann et al. 2006). Recent studies in mice indicated that low dosage of $\mathrm{P}_{4}$ and short activation time (within $30 \mathrm{~min}$ ) are sufficient to reduce oviductal CBF (Bylander et al. 2010, 2013). Therefore, extra-nuclear signaling of CBF through nongenomic actions of $\mathrm{P}_{4}$ without involving a long-delayed genomic regulation may be the cause of direct $\mathrm{CBF}$ regulation.

$E_{2}$ is required to accelerate the transport of the eggs (Orihuela et al. 2001). $\mathrm{E}_{2}$ acts via a non-genomic pathway through protein phosphorylation of PKC and PKA in rats and cows (Orihuela \& Croxatto 2001, Orihuela et al. 2003, Wen et al. 2012). Moreover, in the oviductal secretory cells, $\mathrm{E}_{2}$ induces the production of cAMP, which promotes adrenomedullin activation (Liao et al. 2013). In rats, adrenomedullin increases CBF by acting through the calcitonin-gene-related peptide (CGRP) receptor in the oviductal epithelial cells (Liao et al. 2011).

Published by Bioscientifica Ltd. 
The findings from muscarinic receptor-knockout (Chrm1---, Chrm3 $3^{-/-}$, Chrm $^{-/-}$and Chrm5 $5^{--}$) mice suggest that the cholinergic neuromuscular system is not required for the ciliary beat function, as the particle transport rate in the oviduct remains unchanged compared with their control littermates (Noreikat et al. 2012).

\section{Tubal muscle contraction}

The embryos move back and forth along the oviduct due to the contraction of myosalpinx, with the net progress toward the uterus (Talo 1991). However, studies in rabbits and rats showed that inhibition of muscle contractility does not affect the transport of the embryos (Halbert et al. 1976, 1989). It suggests that at least in these species, ciliary beating alone is capable of transporting the embryos from the oviduct to the uterus. In humans, oxytocin, $\mathrm{P}_{4}$, PGs and nitric oxide participate in the tubal muscle relaxation and contraction (Ekerhovd et al. 1997, Jankovic et al. 2001, Wanggren et al. 2008). $\mathrm{P}_{4}$, through PGR-A and PGR-B relaxes muscle contraction in mice (Conneely et al. 2003). Administration of $\mathrm{P}_{4}$ in the ex vivo culture of human Fallopian tube reduces both amplitude and frequency of tubal muscle contraction (Wanggren et al. 2006); however, treatment with PGR receptor antagonist, mifepristone, has a minimal effect on the contraction. Nevertheless, the exact signaling pathway, beyond the ligand-receptor interaction, through which $\mathrm{P}_{4}$ is involved in directing muscle relaxation remains unclear.

$\mathrm{E}_{2}$ can induce the production of inositol triphosphate (IP3) to increase smooth muscle contraction and accelerate egg transport in the rat oviduct (Orihuela et al. 2006). Additionally, $\mathrm{E}_{2}, \mathrm{P}_{4}$ and endothelin-1 stimulate the release of PGs $\left(\mathrm{PGE}_{2}\right.$ and $\mathrm{PGF}_{2 \alpha}$ ) in bovine oviduct (Wijayagunawardane et al. 2001). Both $\mathrm{PGE}_{2}$ and $\mathrm{PGF}_{2 \alpha}$ are shown to stimulate muscle contraction in human and bovine oviducts (Wijayagunawardane et al. 2001, Wanggren et al. 2008). Endothelin-2 alone can also induce muscle contraction in the rat oviduct through endothelin receptor type A (Al-Alem et al. 2007). These findings indicate that ovarian hormones have both direct effects on stimulating the tubal muscle contraction and indirect effects via the induction of PGs.

Cannabinoid receptor 1 and 2 (Cnr1 and Cnr2), which are $G$ protein-coupled receptors, play crucial roles in pregnancy. Cnr1-/- and Cnr1-/-/Cnr2-/double-knockout mice have significantly higher number of embryos retained in the oviduct (35-46\% retained embryos in the oviduct) compared with
WT control ( $0 \%$ in oviduct) (Wang et al. 2004). This suggests that CNR1 and CNR2 are important for normal embryo transport.

\section{Tubal fluid flow}

Studies assessing the movement of microspheres showed that the orientation of fluid is toward the uterus in rabbits, sheep, cows and guinea pigs, whereas the flow is oriented toward the ovary in the pigs (Gaddum-Rosse \& Blandau 1973, 1976). These results showed that the tubal fluid flow is oriented differently depending on the species. In sheep and rabbits, the oviductal fluid secreted from secretory epithelial cells is increased by female steroid hormones, especially $\mathrm{E}_{2}$ (Hamner \& Fox 1968, McDonald $\&$ Bellve 1969). The fluid production is attenuated when $\mathrm{P}_{4}$ is co-administered with $\mathrm{E}_{2}$, suggesting that $\mathrm{P}_{4}$ opposes $\mathrm{E}_{2}$-induced fluid secretion (Fig. 4). In rabbits, ovariectomy causes decreased secreted fluid in the oviduct, and this fluid level can be restored by $\mathrm{E}_{2}$ treatment (Bishop 1956), suggesting that $\mathrm{E}_{2}$ is the major regulator for secretory fluid production within the oviducts. A recent study in mice demonstrated that inhibition of prolactin, a hormone secreted from the anterior pituitary after mating, using bromocriptine severely reduced the oviductal fluid volume and flow (Miki \& Clapham 2013). The increased oviductal fluid secretion is mostly due to the increased water availability, which is related to the function of the transmembrane water transport proteins, aquaporins (AQPs). In rats, expression of Aqp5, Aqp8 and Aqp9 is regulated by both $\mathrm{E}_{2}$ and $\mathrm{P}_{4}$ (Branes et al. 2005). These findings indicate that $\mathrm{E}_{2}, \mathrm{P}_{4}$ and prolactin play a major role in fluid production in the oviduct. In summary, an overall action of $E_{2}$ is to increase the embryo transport rate by stimulating muscle contraction, inducing fluid production and flow, and increasing the $\mathrm{CBF}$, whereas $\mathrm{P}_{4}$ has an opposite effect of $\mathrm{E}_{2}$ by reducing the embryo transport rate.

\section{Recently identified pathways affecting embryo transport}

The incidence of ectopic pregnancy is one in every 50 normal pregnancies, and $95 \%$ of ectopic pregnancies are associated with defective Fallopian tubes (Tenore 2000). Recent studies demonstrate that some novel pathways contribute to the pathological conditions of Fallopian tubes, with potential ramifications in human infertility.

Published by Bioscientifica Ltd 


\section{Pathways crucial for normal oviduct development}

In the majority of mammals, including rodents and rabbits, a healthy oviduct is a rather coiled tube with no obstructions within to ensure an open passage for eggs, sperm and embryos (Stewart \& Behringer 2012). In humans and non-human primates, however, the coiled structure is not present in the Fallopian tubes. Due to difficulties in obtaining human tissues, scientists have been using genetically engineered mice as a model organism to study the roles of proteins of interest during oviduct development. The recent findings demonstrated that the morphological changes leading to a less coiled or uncoiled oviduct and formation of cysts within the oviduct can result in infertility. Wingless-type integration family member 4 (WNT4) signaling is critical for the development of the female reproductive tract, as female mice lacking Wnt4 expression showed a non-coiled oviduct that lacked folding (Prunskaite-Hyyrylainen et al. 2016). Moreover, overexpression of Notch in the reproductive tract produced similar phenotypes whereby the oviduct failed to coil (Ferguson et al. 2016).

Dicer, an endonuclease responsible for microRNA (miRNA) function, is also crucial for the development of the female reproductive tract. Loss of Dicer in the mouse reproductive tract disrupts oviduct organization by reducing both the length and coiling (Nagaraja et al. 2008, Gonzalez \& Behringer 2009). Additionally, mice lacking Dicer also developed oviductal cysts and severe inflammation in the oviduct at the uterotubal junction. These phenotypes lead to degeneration of the eggs and embryo transport failure. WNT7a is another critical signaling pathway involved in early female reproductive tract development, as a loss of $W n t 7 a$ results in female sterility due to an abnormal development of uterus and oviduct (Parr \& McMahon 1998). These findings indicate that signaling molecules involved in WNT, Notch and miRNA regulation play critical roles in oviductal development and coiling.

\section{Pathways crucial for ciliogenesis and ciliary function}

In addition to organ morphology, disruption of ciliogenesis and ciliated cell differentiation at a cellular level can lead to embryo transport defects. Ciliated epithelial cells in oviducts create tubal currents and are responsible for the transportation of the embryo (Lyons et al. 2006). A comprehensive review regarding cellular and molecular mechanisms governing ciliogenesis is provided in Choksi et al. (2014).
Several recent studies discovered that epithelial cells in the female reproductive tract contain a subpopulation of stem-cell-like LGR5 (leucine-rich repeat-containing G-protein-coupled receptor 5)-positive cells ( $\mathrm{Ng}$ et al. 2014). The LGR5-positive cell population has been identified in other tissues, such as the kidney (Barker $e$ t al. 2012), intestine (Barker et al. 2007) and stomach (Barker et al. 2010). LGR5-positive cells reside much like regular epithelial cells in the tissue, but the characteristics of these cells remain undifferentiated. The LGR5-positive population can be activated to divide and differentiate into designated cell types and is responsible for tissue renewal and regeneration. In the Fallopian tubes, these stem-like adult epithelial cells are concentrated at the fimbria (Paik et al. 2012, Snegovskikh et al. 2014).

Notch and WNT signals not only modulate the oviduct development but also mediate the differentiation of adult epithelial stem cells into other cells in Fallopian tubes (Kessler et al. 2015). Inhibition of Notch signaling by a $\gamma$-secretase inhibitor, dibenzazepine, in the oviduct and the stem-like epithelia leads to a genetic signature of cell differentiation into ciliated epithelium. Inhibition of Notch signaling reduces the number of stem cells in human Fallopian tube 3D organoids, while increasing ciliated cell number. LGR5 also regulates the $\mathrm{WNT} / \beta$-catenin signaling pathway and can be used as a marker for adult oviduct epithelial stem cells (Capel 2014, Ng et al. 2014, Vieira et al. 2015). Studies in mice showed that the deletion of $L g r 5$ in female mice resulted in significantly fewer live births (Sun et al. 2014). These findings suggested that the number of ciliated epithelial cells in the Fallopian tubes is also controlled by the local stem-cell population via the WNT and Notch signaling pathways.

miRNAs also participate in oviductal ciliogenesis. Lacking miRNA-34 and miRNA-499 genes resulted in a loss of cilia in the trachea and oviduct epithelial cells (Wu et al. 2014). Additionally, serine/threonine protein kinase (STK36), a regulator of the hedgehog pathway, modulates a central pair construction of the cilia (the two center microtubules in the $9+2$ microtubule axonemal structure). A lack of Stk36 causes an impairment of the cilia orientation and results in a failure to form the directional movement of the cilia in the oviduct (Nozawa et al. 2013). Moreover, a global deletion of Kif19a, a kinesis family member involved in cilia length regulation, causes female infertility due to elongated cilia in the oviduct (Niwa et al. 2012). Elongated cilia in the Kif19a- oviduct lead to excess mucus and cell debris in the oviductal lumen and blockage of the egg passage.

Published by Bioscientifica Ltd 
In addition, female mice lacking Celsr 1 (Celsr1---), a planar cell polarity gene, showed defective ciliary polarity, which resulted in a random orientation of cilia directionality. The impaired cilia were unable to transport beads in a uniform direction, which disrupted the transportation function of the oviduct (Shi et al. 2014). In conclusion, the presence, proper length, proper structure and directionality of the cilia are crucial for the oviduct transport function to support the gametes and embryos.

\section{In vitro fertilization and embryo development}

With recent technological advancement such as IVF and ICSI, infertility clinics can now provide solutions to allow infertile couples to conceive their own children. Procedures can bypass the Fallopian tube entirely and transfer the fertilized embryos directly into the uterus. The presence of these technologies questions the role of the oviduct and its necessity for human reproduction. ARTs are common procedure worldwide, including IVF and ICSI. However, not every couple has access to ARTs due to economical limitation. Moreover, there are several concerns regarding the use of ARTs, such as epigenetic change in the embryos due to culture conditions and controlled ovarian hyperstimulation $(\mathrm{COH})$, complicated pregnancy due to multiple gestation and a lack of natural section (especially with ICSI). Therefore, the medical research community should take precaution and study possible complications with such technologies when bringing hope to many couples experiencing infertility.

For many couples with fertility issues, IVF may be their only hope to have offspring inheriting their genes. It is a technique whereby the clinicians fertilize the eggs with sperm outside the female reproductive tract and incubate the fertilized embryos in a laboratory until they are ready for implantation in the uterus. IVF has been practiced for decades throughout the world and has resulted in over 3.5-5 million newborns across the globe. The international committee for monitoring ART reported that with one million documented cases, the pregnancy rate of IVF/ICSI is $20-30 \%$ (Mansour et al. 2014) compared with $45-85 \%$ after 3-12 month conceived naturally (Luke et al. 2012).

A recent study from more than 178,000 women who went through IVF treatment suggested that an overall successful live birth rate through IVF pregnancy is $43 \%$ (McLernon et al. 2016). When a woman is over 38 years old, live birth success through IVF drops significantly to $21 \%$ (Stern et al. 2009). Compared with natural conception, IVF/ICSI-conceived embryos have a significantly higher risk of perinatal mortality, low birth weight and preterm birth (Pandey et al. 2012, Pinborg et al. 2013, Marino et al. 2014). When comparing IVF/ICSI with naturally conceived children, there is a 3-4 times higher chance for imprinting disorders, including Beckwith-Wiedemann syndrome, Prader-Willi syndrome, Angelman syndrome, SilverRussell syndrome, transient neonatal diabetes mellitus, McCune-Albright syndrome, familial nonchromaffin paraganglioma, maternal hypomethylation syndrome and retinoblastoma in IVF/ICSI children (Owen \& Segars 2009, Lazaraviciute et al. 2014).

A study comparing 7- to 8-year-old children who were conceived through IVF/ICSI and natural intercourse found that there is no difference in their cognitive ability, but there is an underlying gender difference (Punamaki et al. 2016). Naturally conceived boys showed more cognitive developmental problems than girls, whereas no differences were observed between boys and girls conceived through IVF. This study, however, is solely dependent on parental reports and may have a bias between IVF and naturally conceived parents. In terms of imprinting disorder, there is increased evidence of Beckwith-Wiedemann Syndrome in the IVF/ICSI-conceived children (4\%) compared with naturally conceived children (0.7-1.2\%) in a small cohort of 149 children in the UK (Maher et al. 2003). There is reduced methylation in KvDMR, an intronic CpG island in the KCNQ1 (or KvLQT1) gene whose methylation status is associated with Beckwith-Wiedemann Syndrome (Smilinich et al. 1999), in the embryonic tissues conceived by the IVF method (Gomes et al. 2007).

With ever-improving biotechnology, more studies are required to understand the implications of the health and wellbeing of IVF individuals. As IVF-conceived individuals are still in their reproductive ages, long-term evaluation on transgenerational epigenetic outcomes will be needed.

\section{Epigenetics and environmental factors}

Embryos go through epigenetic changes and result in imprinting, which has a long-lasting effect in later development. Cell fate is not determined in the embryo before the morula stage. The early embryos repress epigenetic modification by removing DNA methylation and repressing histone modifications from the 2-cell stage until the blastocyst stage in mice (Reik et al. 2001,

Published by Bioscientifica Ltd 
Ma et al. 2012) and until the 8-cell stage in cows (Dean et al. 2001). However, the demethylation timing of DNA methylation in the embryo is on a gene-by-gene basis (Messerschmidt et al. 2014). In humans, DNA demethylation occurs much earlier compared with other mammals, from fertilization to the 2-cell stage, at which time, most genes tested have already lost their methylation status (Guo et al. 2014, Okae et al. 2014). For example, 5' long terminal repeat-containing element is demethylated after fertilization (Smith et al. 2014). As embryos develop to the blastocyst stage, repression is slowly reversed in the inner cell mass, and methylation status becomes increased (Smith et al. 2012, Guo et al. 2014, Okamoto et al. 2016).

\section{Epigenetics}

A recent review discussed how ARTs influence the epigenetics of early embryos and suggested that gene expression in developing embryos could be altered through the environment in which they interact (Lucas 2013). COH is one of the common hormonal regimens used to induce ovulation, either alone or as part of the IVF/ICSI procedures (Farhi \& Orvieto 2010, Berker et al. 2011). Studies using in vitro maturated (IVM) human oocytes (retrieved from gonadotropin-stimulated patients) demonstrate that the wildly used oocyte morphological maturation protocol may not necessarily indicate an adequate maturation of gene expression (Jones et al. 2008, Virant-Klun et al. 2013). These genes are involved in meiosis (SYCP2, SGOL2 and MSH2) and are upregulated in the IVM oocytes compared with in vivo maturated oocytes. Ovarian-stimulated IVM-derived mouse embryos express incomplete DNA demethylation at the 2-cell stage. Aberrant methylation in the mouse embryo can be an indication of failure in embryo development (Shi \& Haaf 2002, Wang et al. 2010). The evidence showed that in vitro pre-implantation mouse embryo culture results in a selective loss of imprinting gene expression of imprinted maternally expressed transcript (H19) and small nuclear ribonucleoprotein polypeptide $\mathrm{N}(S N R P N)$ due to a reduced methylation on their control regions (Mann et al. 2004). Moreover, several studies showed that the culture of mouse embryos in different media compositions could lead to epigenetic changes and contribute to developmental defects and aberrant phenotypes in adulthood (Reik et al. 1993, Dean et al. 1998, Khosla et al. 2001). These findings indicated that media composition and $\mathrm{COH}$ could contribute to epigenetic alterations in the embryos.
A recent study using cord blood and placentas collected from the children conceived by ART and naturally conceived children showed that the source of alteration in DNA methylation status is a result of ART procedures, rather than the underlying fertility of the parents (Song et al. 2015). Hiura and coworkers proposed that imprinting disorders are a combination of heredity, senescent, $\mathrm{COH}, \mathrm{ART}$ procedures and culture medium that potentiates the early onset of the diseases (Hiura et al. 2014). This evidence outlines the important link between ARTs and epigenetic imprinting outcomes in children.

\section{Oxygen tension}

The physiological level of $\mathrm{O}_{2}$ concentration is $8 \%$ (Fischer \& Bavister 1993). However, IVF embryos are cultured in various oxygen concentrations in different set-ups (5-20\%) (Bontekoe et al. 2012), which can impact the level of oxidative stress on the embryos. Depends on the culture media composition, the glutathione pool in human oocytes can be depleted, resulting in high ROS and causing plasma membrane damage to the oocytes (Martin-Romero et al. 2008). A recent study using post-thawed human embryos found that at $2 \% \mathrm{O}_{2}$ concentration in the culture, embryos

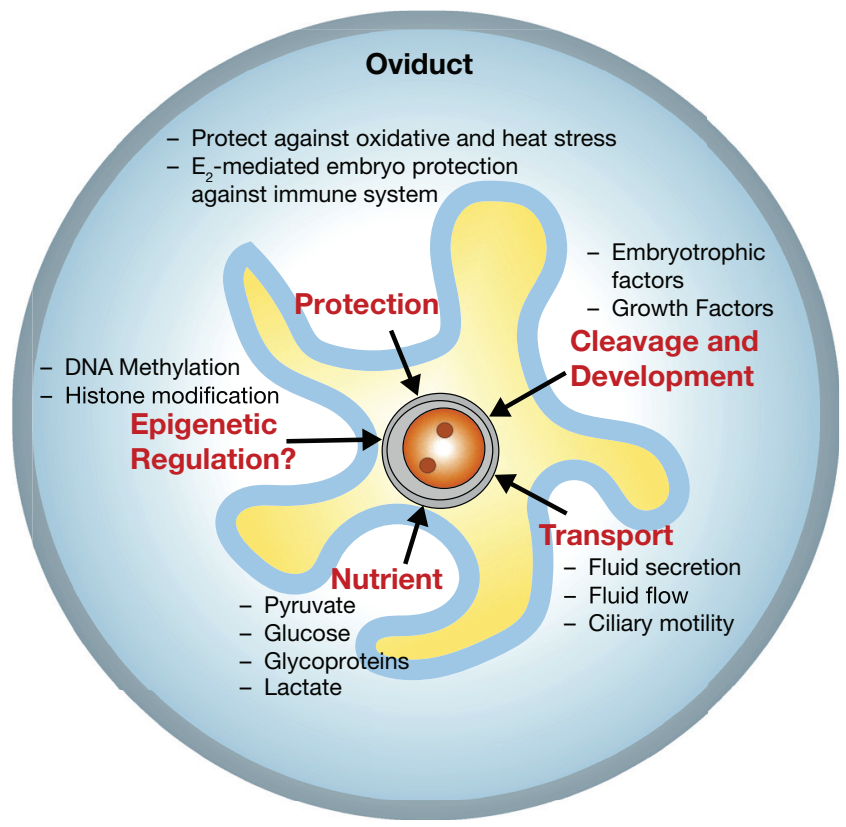

Figure 5

Essential roles of the oviduct in assisting embryo development. Schematic cross-section of the oviduct and the embryo with their interaction regulating embryo development. The interactions are divided into five domains: protection, cleavage and development, transport, nutrients and epigenetic regulation. $\mathrm{E}_{2}$, estrogen.

Published by Bioscientifica Ltd. 

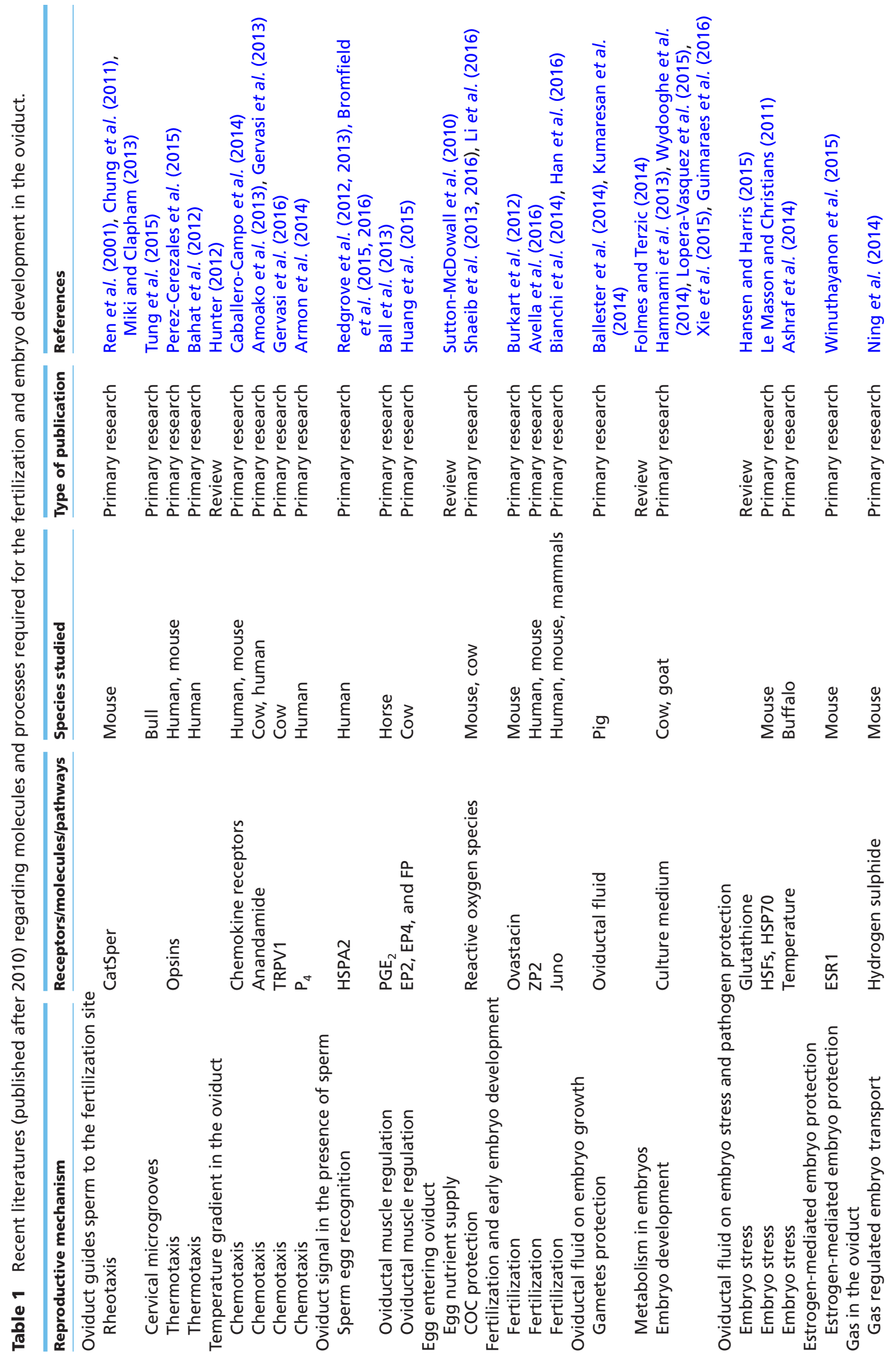

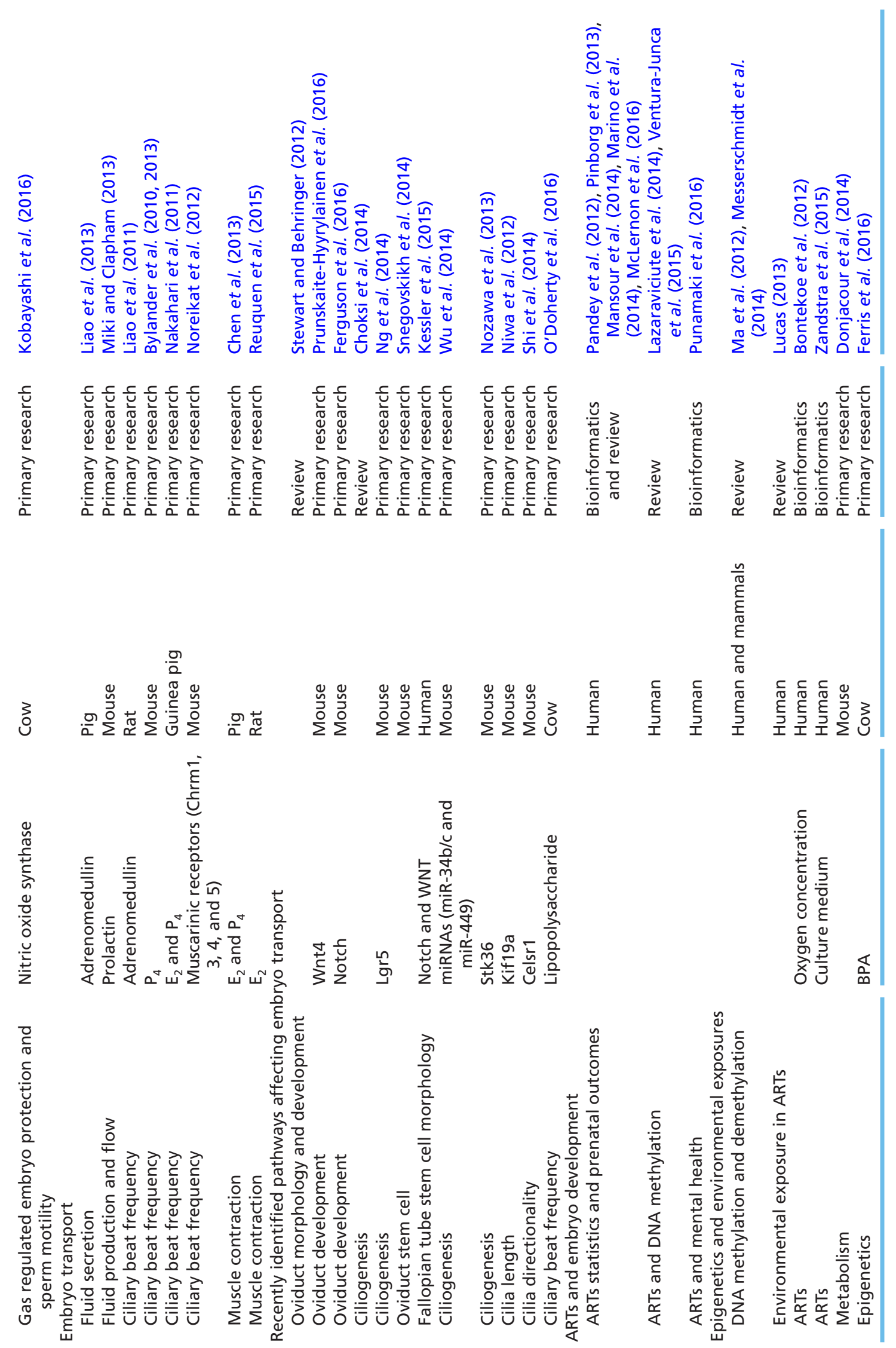
have a decreased survival rate and increased apoptotic rate. On the contrary, when the $\mathrm{O}_{2}$ level is slightly below the physiological level (5-6\%), the embryos did not show any significant change in those parameters (Yang et al. 2016). The authors suggested that the culture condition at 5-6\% $\mathrm{O}_{2}$ concentration could improve the survival rate of the embryos. However, recent randomized control studies did not find a robust correlation between the culture of human embryos at $5-6 \% \mathrm{O}_{2}$ concentration and the increase in the live birth rate (Nastri et al. 2016).

Yang and coworkers also found that cell death genes $(B A X)$, antioxidant genes $(\mathrm{MnSOD})$ and stress protective genes (HSP7O) are elevated and apoptosis is increased in human embryos that were cultured at a $20 \% \mathrm{O}_{2}$ level (Yang et al. 2016). In addition, mouse embryos cultured in $20 \% \mathrm{O}_{2}$ showed pre-implantation epigenetic changes that altered metabolism later in life (Donjacour et al. 2014). Specifically, male mice displayed glucose intolerance, heavier body weight and heart enlargement compared with in vivo fertilized embryos. This evidence indicates that the in vitro culture conditions during ART procedures, either at low or high $\mathrm{O}_{2}$ concentration, could potentially alter embryo development and lead to metabolic disease in mammals.

\section{Environmental exposures}

The pre-implantation period is critical for embryo epigenetic control; this period normally occurs in the oviduct or Fallopian tube in humans. Factors known to be different between IVF and natural development can cause epigenetic influence, including techniques, embryo culture media and environmental exposures such as tissue culture plastics (Ventura-Junca et al. 2015). Bisphenol A (BPA) is known for its action as an endocrine-disrupting compound and a weak estrogen agonist/antagonist. However, BPA is still being used as part of the plastic containers for embryo cultures (Hunt et al. 2003, Berger et al. 2010, Varayoud et al. 2011). Studies indicated a broad range of effects on the embryos upon BPA exposure, such as altered developmental rate and cell death (Ferris et al. 2016) and toxicity to the neural progenitor cells (Yin et al. 2015). BPA-free replacement products from the industry still diffuse out estrogenic chemicals, such as BPAF (the fluorinated form of BPA) (Bittner et al. 2014), which may pose a significant hazard to the embryos.

Together, we need to take extreme precaution to monitor the in vitro environment of IVM and IVF/ICSI procedures and the possible unwanted consequences on the long-term epigenetic imprints.

\section{Developmental factors missing in vitro}

The most distinct physiological difference between IVF and naturally conceived birth is the artificial fertilization and the omission of development in the in vivo environments. IVF procedures cultivate fertilized embryos in the culture conditions until the embryos are ready for uterine implantation. Depending on the procedures and institutional protocols, it can be anywhere between 3 and 7 days of in vitro development. The culture media is pre-determined and static compared with a dynamic, interactive Fallopian tube environment. This static environment at the current state cannot provide an interactive response to ROS produced by embryos. Moreover, the viability of the IVF embryos is subjective to institutional procedures.

Of the factors influencing embryo development in vitro, the foremost is the culture media used to culture embryos. This media is meant to mimic the oviductal fluid and its nutrient composition to support early cleavage development. A data analysis study suggested that in humans, the embryo culture media could affect the birthweight of IVF babies (Zandstra et al. 2015); however, the underlying mechanism is not well understood. The oviductal environment, the fluid and the embryo interaction with the environment are difficult to replicate in vitro. This factor could lead to the difference between IVF and natural birth. A known example occurs in very early embryo development; hyaluronan acid synthase 1 (HAS1) is highly expressed in the embryo at the 2- to 4-cell stage, but then quickly fades away (Marei et al. 2013). The oviduct reacts to this change by expressing hyaluronidase-2 (HYAL-2) to degrade excessive hyaluronan acid (HA). In vitro studies in bovine demonstrated that mimicking this embryo-oviduct interaction by adding HYAL-2 to the culture media improves embryo quality (Marei et al. 2013).

Bovine embryos fertilized in vitro have lower quality than those fertilized in vivo, as indicated by the difference in the cellular junction, the presence of lipid droplets and other subcellular changes. Co-culture of human embryos with the Fallopian epithelia improved the quality of embryos (Yeung et al. 1992, Vlad et al. 1996). However, analysis in humans suggested that simply mimicking the in vivo environment using an in vitro model did not increase the baby delivery rate (Stern et al. 2009). This

Published by Bioscientifica Ltd. 
could be the result of a complex interaction among embryo, tubal epithelia and tubal fluid. An extensive review by Hess and coworkers discussed the important roles of the oviduct in stabilizing the very early stage of embryo development during transit (Hess et al. 2013). Therefore, the oviduct-embryo interaction is necessary for the quality of the developing embryo and lacking this interaction could result in negative health effects.

Another difference between IVF and in vivo fertilization is the zona pellucida hardening and monospermy during fertilization (Mondejar et al. 2013, Anifandis et al. 2016, Dadashpour Davachi et al. 2016). In a natural pregnancy, the female reproductive tract acts as a passage for sperm selection, by which it minimizes the number of sperm reaching the fertilization site to ensure that polyspermy occurs at a low rate. Current IVF techniques cannot effectively select the most superior sperm, which occurs naturally in the female reproductive tract. To overcome this, one could use a co-culture condition of the egg and oviduct epithelia. An experiment demonstrated that co-culture of eggs and oviductal epithelial cells is significantly better at preventing polyspermic fertilization than the standard IVF counterpart (Dadashpour Davachi et al. 2016). This suggests that fertilization in the oviduct is part of a continuing interaction between gametes and oviduct to optimize the fertilization outcome.

Lastly, gas is a factor that we have ignored in most cases. Embryos experience somewhere between 2\% and $8 \% \mathrm{O}_{2}$ concentrations in the human Fallopian tube (Bontekoe et al. 2012). However, in the IVF procedures, the embryos are incubated at different oxygen levels, from $5 \%$ to $20 \%$. The effect of these $\mathrm{O}_{2}$ percentages in the culture compared with in vivo has not been well studied, but it would be wise to take precaution because high oxygen concentration is linked to oxidation stress (Fischer \& Bavister 1993, Catt \& Henman 2000).

The retrospective on IVF studies suggests that Fallopian tubes not only serve as the passage for the embryo to enter the uterus but also act as a cofactor to cultivate and optimize embryo quality to ensure successful implantation and later normal development.

\section{Conclusion}

The oviduct is essential in reproduction. Before fertilization, the oviduct primes the sperm, protects both gametes and guilds the fertilization process through distinct mechanisms, including rheotaxis, thermotaxis and chemotaxis. Increasing evidence indicates that processes that occur in the oviduct facilitate the path to fertilization, but detailed molecular mechanisms regarding each step are still largely unknown. Most importantly, the oviduct provides the optimized physical site for fertilization to occur.

After fertilization, the oviduct adjusts each of its components to ensure the survival and the normal development of the embryo, summarized in Fig. 5; the current literature regarding these aspects is included in Table 1 . The oviductal fluid contains nutrients, growth factors, antioxidants, sex hormones, proteases and many other functional chemicals regulated by the presence of gametes and embryos. The oviduct also transports the embryo from the site of fertilization into the uterus. Defective embryo transport can cause infertility or ectopic pregnancy. Most recent findings suggested that a few new pathways involved in this process, along with ciliated cells, contribute a major role in this transport. Together, the oviduct fine-tunes the oviductal fluid to ensure that the embryos receive proper developmental signals and nutrients as well as helps embryos overcome environmental stress and protects embryos from our own immune system.

The oviduct has been under-appreciated with its 'nonessential' role in reproduction since the success of IVF over 30 years ago. However, there have been more studies probing the downside of the ARTs that link to some of the critical functionalities of the oviduct to embryo development. ARTs can be further improved with these findings. At the same time, precautions should be taken, as more research is needed for the roles and functions of the oviduct in fertilization and embryo development to benefit the health of future generations.

Declaration of interest

The authors declare that there is no conflict of interest that could be perceived as prejudicing the impartiality of this review.

\section{Funding}

This work was supported by start-up fund from Washington State University.

\section{References}

Absalon-Medina VA, Butler WR \& Gilbert RO 2014 Preimplantation embryo metabolism and culture systems: experience from domestic animals and clinical implications. Journal of Assisted Reproduction and Genetics 31 393-409. (doi:10.1007/s10815-014-0179-2)

Adachi K, Kurachi H, Homma H, Adachi H, Imai T, Sakata M, Higashiguchi O, Yamaguchi M, Morishige K, Sakoyama Y, et al. 1995 Estrogen induces epidermal growth factor (EGF) receptor

Published by Bioscientifica Ltd. 
and its ligands in human fallopian tube: involvement of EGF but not transforming growth factor-alpha in estrogen-induced tubal cell growth in vitro. Endocrinology 136 2110-2119. (doi:10.1210/ endo.136.5.7720660)

Agbor TA, Demma Z, Mrsny RJ, Castillo A, Boll EJ \& McCormick BA 2014 The oxido-reductase enzyme glutathione peroxidase 4 (GPX4) governs Salmonella Typhimurium-induced neutrophil transepithelial migration. Cellular Microbiology 16 1339-1353. (doi:10.1111/ cmi.12290)

Al-Alem L, Bridges PJ, Su W, Gong MC, Iglarz M \& Ko C 2007 Endothelin-2 induces oviductal contraction via endothelin receptor subtype A in rats. Journal of Endocrinology 193 383-391. (doi:10.1677/ JOE-07-0089)

Alvarez JG \& Storey BT 1983 Taurine, hypotaurine, epinephrine and albumin inhibit lipid peroxidation in rabbit spermatozoa and protect against loss of motility. Biology of Reproduction 29 548-555. (doi:10.1095/biolreprod29.3.548)

Amoako AA, Marczylo TH, Marczylo EL, Elson J, Willets JM, Taylor AH \& Konje JC 2013 Anandamide modulates human sperm motility: implications for men with asthenozoospermia and oligoasthenoteratozoospermia. Human Reproduction 28 2058-2066. (doi:10.1093/humrep/det232)

Anderson RA Jr, Feathergill KA, Rawlins RG, Mack SR \& Zaneveld LJ 1995 Atrial natriuretic peptide: a chemoattractant of human spermatozoa by a guanylate cyclase-dependent pathway. Molecular Reproduction and Development 40 371-378. (doi:10.1002/mrd.1080400314)

Andrade YN, Fernandes J, Vazquez E, Fernandez-Fernandez JM, Arniges M, Sanchez TM, Villalon M \& Valverde MA 2005 TRPV4 channel is involved in the coupling of fluid viscosity changes to epithelial ciliary activity. Journal of Cell Biology 168 869-874. (doi:10.1083/jcb.200409070)

Anifandis G, Messini CI, Dafopoulos K, Daponte A \& Messinis IE 2016 Sperm contributions to oocyte activation: more that meets the eye. Journal of Assisted Reproduction and Genetics 33 313-316. (doi:10.1007/ s10815-016-0653-0)

Aquila S, Guido C, Laezza C, Santoro A, Pezzi V, Panza S, Ando S \& Bifulco M 2009 A new role of anandamide in human sperm: focus on metabolism. Journal of Cellular Physiology 221 147-153. (doi:10.1002/ jcp.21837)

Aquila S, Guido C, Santoro A, Perrotta I, Laezza C, Bifulco M \& Sebastiano A 2010 Human sperm anatomy: ultrastructural localization of the cannabinoid1 receptor and a potential role of anandamide in sperm survival and acrosome reaction. Anatomical Record 293 298-309. (doi:10.1002/ar.21042)

Ardon F, Markello RD, Hu L, Deutsch ZI, Tung CK, Wu M \& Suarez SS 2016 Dynamics of bovine sperm interaction with epithelium differ between oviductal isthmus and ampulla. Biology of Reproduction 95 90. (doi:10.1095/biolreprod.116.140632)

Armon L, Ben-Ami I, Ron-El R \& Eisenbach M 2014 Human oocytederived sperm chemoattractant is a hydrophobic molecule associated with a carrier protein. Fertility and Sterility 102 885-890. (doi:10.1016/j.fertnstert.2014.06.011)

Ashraf S, Shah SM, Saini N, Dhanda S, Kumar A, Goud TS, Singh MK, Chauhan MS \& Upadhyay RC 2014 Developmental competence and expression pattern of bubaline (Bubalus bubalis) oocytes subjected to elevated temperatures during meiotic maturation in vitro. Journal of Assisted Reproduction and Genetics 31 1349-1360. (doi:10.1007/s10815014-0275-3)

Avella MA, Baibakov BA, Jimenez-Movilla M, Sadusky AB \& Dean J 2016 ZP2 peptide beads select human sperm in vitro, decoy mouse sperm in vivo, and provide reversible contraception. Science Translational Medicine 8 336ra360. (doi:10.1126/scitranslmed.aad9946)

Bahat A, Tur-Kaspa I, Gakamsky A, Giojalas LC, Breitbart H \& Eisenbach M 2003 Thermotaxis of mammalian sperm cells: a potential navigation mechanism in the female genital tract. Nature Medicine 9 149-150. (doi:10.1038/nm0203-149)
Bahat A, Eisenbach M \& Tur-Kaspa I 2005 Periovulatory increase in temperature difference within the rabbit oviduct. Human Reproduction 20 2118-2121. (doi:10.1093/humrep/dei006)

Bahat A, Caplan SR \& Eisenbach M 2012 Thermotaxis of human sperm cells in extraordinarily shallow temperature gradients over a wide range. PLoS ONE 7 e41915. (doi:10.1371/journal.pone.0041915)

Ball BA, Scoggin KE, Troedsson MH \& Squires EL 2013 Characterization of prostaglandin E2 receptors (EP2, EP4) in the horse oviduct. Animal Reproduction Science 142 35-41. (doi:10.1016/j. anireprosci.2013.07.009)

Ballester L, Romero-Aguirregomezcorta J, Soriano-Ubeda C, Matas C, Romar R \& Coy P 2014 Timing of oviductal fluid collection, steroid concentrations, and sperm preservation method affect porcine in vitro fertilization efficiency. Fertility and Sterility $\mathbf{1 0 2}$ 1762.e1761-1768.e1761. (doi:10.1016/j.fertnstert.2014.08.009)

Barker N, van Es JH, Kuipers J, Kujala P, van den Born M, Cozijnsen M, Haegebarth A, Korving J, Begthel H, Peters PJ, et al. 2007 Identification of stem cells in small intestine and colon by marker gene Lgr5. Nature 449 1003-1007. (doi:10.1038/nature06196)

Barker N, Huch M, Kujala P, van de Wetering M, Snippert HJ, van Es JH, Sato T, Stange DE, Begthel $\mathrm{H}$, van den Born M, et al. 2010 Lgr5(+ve) stem cells drive self-renewal in the stomach and build long-lived gastric units in vitro. Cell Stem Cell 6 25-36. (doi:10.1016/ j.stem.2009.11.013)

Barker N, Rookmaaker MB, Kujala P, Ng A, Leushacke M, Snippert H, van de Wetering M, Tan S, Van Es JH, Huch M, et al. 2012 Lgr5(+ve) stem/progenitor cells contribute to nephron formation during kidney development. Cell Reports 2 540-552. (doi:10.1016/ j.celrep.2012.08.018)

Basavarajappa BS, Nagre NN, Xie S \& Subbanna S 2014 Elevation of endogenous anandamide impairs LTP, learning, and memory through CB1 receptor signaling in mice. Hippocampus 24 808-818. (doi:10.1002/hipo.22272)

Beier HM 1974 Oviducal and uterine fluids. Journal of Reproduction and Fertility 37 221-237. (doi:10.1530/jrf.0.0370221)

Berger RG, Foster WG \& deCatanzaro D 2010 Bisphenol-A exposure during the period of blastocyst implantation alters uterine morphology and perturbs measures of estrogen and progesterone receptor expression in mice. Reproductive Toxicology 30 393-400. (doi:10.1016/j.reprotox.2010.06.006)

Berker B, Kahraman K, Taskin S, Sukur YE, Sonmezer M \& Atabekoglu CS 2011 Recombinant FSH versus clomiphene citrate for ovarian stimulation in couples with unexplained infertility and male subfertility undergoing intrauterine insemination: a randomized trial. Archives of Gynecology and Obstetrics 284 1561-1566. (doi:10.1007/ s00404-011-1997-4)

Betteridge KJ \& Mitchell D 1974 Direct evidence of retention of unfertilized ova in the oviduct of the mare. Journal of Reproduction and Fertility 39 145-148. (doi:10.1530/jrf.0.0390145)

Bian F, Mao G, Guo M, Mao G, Wang J, Li J, Han Y, Chen X, Zhang M \& Xia G 2012 Gradients of natriuretic peptide precursor A (NPPA) in oviduct and of natriuretic peptide receptor 1 (NPR1) in spermatozoon are involved in mouse sperm chemotaxis and fertilization. Journal of Cellular Physiology 227 2230-2239. (doi:10.1002/jcp.22962)

Bianchi E, Doe B, Goulding D \& Wright GJ 2014 Juno is the egg Izumo receptor and is essential for mammalian fertilization. Nature $\mathbf{5 0 8}$ 483-487. (doi:10.1038/nature13203)

Bishop DW 1956 Active secretion in the rabbit oviduct. American Journal of Physiology 187 347-352.

Bittner GD, Yang CZ \& Stoner MA 2014 Estrogenic chemicals often leach from BPA-free plastic products that are replacements for BPA-containing polycarbonate products. Environmental Health 1341. (doi:10.1186/1476-069X-13-41)

Bontekoe S, Mantikou E, van Wely M, Seshadri S, Repping S \& Mastenbroek S 2012 Low oxygen concentrations for embryo culture

Published by Bioscientifica Ltd. 
in assisted reproductive technologies. Cochrane Database of Systematic Reviews 7 CD008950. (doi:10.1002/14651858.CD008950.pub2)

Branes MC, Morales B, Rios M \& Villalon MJ 2005 Regulation of the immunoexpression of aquaporin 9 by ovarian hormones in the rat oviductal epithelium. American Journal of Physiology: Cell Physiology 288 C1048-C1057. (doi:10.1152/ajpcell.00420.2003)

Bromfield EG, Aitken RJ, Anderson AL, McLaughlin EA \& Nixon B 2015 The impact of oxidative stress on chaperone-mediated human sperm-egg interaction. Human Reproduction 30 2597-2613. (doi:10.1093/humrep/dev214)

Bromfield EG, McLaughlin EA, Aitken RJ \& Nixon B 2016 Heat Shock Protein member A2 forms a stable complex with angiotensin converting enzyme and protein disulfide isomerase A6 in human spermatozoa. Molecular Human Reproduction 22 93-109. (doi:10.1093/ molehr/gav073)

Burkart AD, Xiong B, Baibakov B, Jimenez-Movilla M \& Dean J 2012 Ovastacin, a cortical granule protease, cleaves ZP2 in the zona pellucida to prevent polyspermy. Journal of Cell Biology 197 37-44. (doi:10.1083/jcb.201112094)

Bylander A, Nutu M, Wellander R, Goksor M, Billig H \& Larsson DG 2010 Rapid effects of progesterone on ciliary beat frequency in the mouse fallopian tube. Reproductive Biology and Endocrinology 848. (doi:10.1186/1477-7827-8-48)

Bylander A, Lind K, Goksor M, Billig H \& Larsson DG 2013 The classical progesterone receptor mediates the rapid reduction of fallopian tube ciliary beat frequency by progesterone. Reproductive Biology and Endocrinology 11 33. (doi:10.1186/1477-7827-11-33)

Caballero-Campo P, Buffone MG, Benencia F, Conejo-Garcia JR, Rinaudo PF \& Gerton GL 2014 A role for the chemokine receptor CCR6 in mammalian sperm motility and chemotaxis. Journal of Cellular Physiology 229 68-78. (doi:10.1002/jcp.24418)

Capel B 2014 Ovarian epithelium regeneration by Lgr5(+) cells. Nature Cell Biology 16 743-744. (doi:10.1038/ncb3020)

Carlsson B, Hillensjo T, Nilsson A, Tornell J \& Billig H 1993 Expression of insulin-like growth factor-I (IGF-I) in the rat fallopian tube: possible autocrine and paracrine action of fallopian tube-derived IGF-I on the fallopian tube and on the preimplantation embryo. Endocrinology 133 2031-2039. (doi:10.1210/endo.133.5.8404650)

Catt JW \& Henman M 2000 Toxic effects of oxygen on human embryo development. Human Reproduction 15 (Supplement 2) 199-206. (doi:10.1093/humrep/15.suppl_2.199)

Chang H \& Suarez SS 2012 Unexpected flagellar movement patterns and epithelial binding behavior of mouse sperm in the oviduct. Biology of Reproduction 86 140, 141-148. (doi:10.1095/biolreprod.111.096578)

Chegini N, Zhao Y \& McLean FW 1994 Expression of messenger ribonucleic acid and presence of immunoreactive proteins for epidermal growth factor (EGF), transforming growth factor alpha (TGF alpha) and EGF/TGF alpha receptors and 125I-EGF binding sites in human fallopian tube. Biology of Reproduction 50 1049-1058. (doi:10.1095/biolreprod50.5.1049)

Chen S, Einspanier R \& Schoen J 2013 In vitro mimicking of estrous cycle stages in porcine oviduct epithelium cells: estradiol and progesterone regulate differentiation, gene expression, and cellular function. Biology of Reproduction 89 54. (doi:10.1095/biolreprod.113.108829)

Choksi SP, Lauter G, Swoboda P \& Roy S 2014 Switching on cilia: transcriptional networks regulating ciliogenesis. Development 141 1427-1441. (doi:10.1242/dev.074666)

Christians E, Campion E, Thompson EM \& Renard JP 1995 Expression of the HSP 70.1 gene, a landmark of early zygotic activity in the mouse embryo, is restricted to the first burst of transcription. Development 121 113-122.

Christians E, Michel E \& Renard JP 1997 Developmental control of heat shock and chaperone gene expression. Hsp 70 genes and heat shock factors during preimplantation phase of mouse development. Cellular and Molecular Life Sciences 53 168-178. (doi:10.1007/PL00000589)
Chung JJ, Navarro B, Krapivinsky G, Krapivinsky L \& Clapham DE 2011 A novel gene required for male fertility and functional CATSPER channel formation in spermatozoa. Nature Communications 2153. (doi:10.1038/ncomms1153)

Conneely OM, Mulac-Jericevic B \& Lydon JP 2003 Progesteronedependent regulation of female reproductive activity by two distinct progesterone receptor isoforms. Steroids 68 771-778. (doi:10.1016/ S0039-128X(03)00126-0)

Couse JF \& Korach KS 1999 Estrogen receptor null mice: what have we learned and where will they lead us? Endocrine Reviews 20 358-417. (doi:10.1210/edrv.20.3.0370)

Cretoiu SM, Cretoiu D, Suciu L \& Popescu LM 2009 Interstitial Cajal-like cells of human Fallopian tube express estrogen and progesterone receptors. Journal of Molecular Histology 40 387-394. (doi:10.1007/ s10735-009-9252-z)

Croxatto HB 2002 Physiology of gamete and embryo transport through the fallopian tube. Reproductive BioMedicine Online 4 160-169. (doi:10.1016/S1472-6483(10)61935-9)

Dadashpour Davachi N, Zare Shahneh A, Kohram H, Zhandi M, Shamsi H, Hajiyavand AM \& Saadat M 2016 Differential influence of ampullary and isthmic derived epithelial cells on zona pellucida hardening and in vitro fertilization in ovine. Reproductive Biology 16 61-69. (doi:10.1016/j.repbio.2015.11.002)

Daliri M, Rao KB, Kaur G, Garg S, Patil S \& Totey SM 1999 Expression of growth factor ligand and receptor genes in preimplantation stage water buffalo (Bubalus bubalis) embryos and oviduct epithelial cells. Journal of Reproduction and Fertility 117 61-70. (doi:10.1530/ jrf.0.1170061)

De Blas GA, Darszon A, Ocampo AY, Serrano CJ, Castellano LE, Hernandez-Gonzalez EO, Chirinos M, Larrea F, Beltran C \& Trevino CL 2009 TRPM8, a versatile channel in human sperm. PLOS ONE 4 e6095. (doi:10.1371/journal.pone.0006095)

Dean W, Bowden L, Aitchison A, Klose J, Moore T, Meneses JJ, Reik W \& Feil R 1998 Altered imprinted gene methylation and expression in completely ES cell-derived mouse fetuses: association with aberrant phenotypes. Development 125 2273-2282.

Dean W, Santos F, Stojkovic M, Zakhartchenko V, Walter J, Wolf E \& Reik W 2001 Conservation of methylation reprogramming in mammalian development: aberrant reprogramming in cloned embryos. PNAS 98 13734-13738. (doi:10.1073/pnas.241522698)

Dobrinski I, Smith TT, Suarez SS \& Ball BA 1997 Membrane contact with oviductal epithelium modulates the intracellular calcium concentration of equine spermatozoa in vitro. Biology of Reproduction 56 861-869. (doi:10.1095/biolreprod56.4.861)

Donjacour A, Liu X, Lin W, Simbulan R \& Rinaudo PF 2014 In vitro fertilization affects growth and glucose metabolism in a sex-specific manner in an outbred mouse model. Biology of Reproduction 9080. (doi:10.1095/biolreprod.113.113134)

Dumollard R, Duchen M \& Carroll J 2007a The role of mitochondrial function in the oocyte and embryo. Current Topics in Developmental Biology 77 21-49. (doi:10.1016/S0070-2153(06)77002-8)

Dumollard R, Ward Z, Carroll J \& Duchen MR 2007b Regulation of redox metabolism in the mouse oocyte and embryo. Development 134 455-465. (doi:10.1242/dev.02744)

Ekerhovd E, Brannstrom M, Alexandersson M \& Norstrom A 1997 Evidence for nitric oxide mediation of contractile activity in isolated strips of the human Fallopian tube. Human Reproduction 12 301-305. (doi:10.1093/humrep/12.2.301)

El Mouatassim S, Guerin P \& Menezo Y 2000 Mammalian oviduct and protection against free oxygen radicals: expression of genes encoding antioxidant enzymes in human and mouse. European Journal of Obstetrics and Gynecology and Reproductive Biology 89 1-6. (doi:10.1016/S0301-2115(99)00169-4)

Eyestone WH \& First NL 1989 Co-culture of early cattle embryos to the blastocyst stage with oviducal tissue or in conditioned medium.

Published by Bioscientifica Ltd. 
Journal of Reproduction and Fertility 85 715-720. (doi:10.1530/ jrf.0.0850715)

Farhi J \& Orvieto R 2010 Cumulative clinical pregnancy rates after $\mathrm{COH}$ and IUI in subfertile couples. Gynecological Endocrinology 26 500-504. (doi:10.3109/09513590903367036)

Ferguson L, Kaftanovskaya EM, Manresa C, Barbara AM, Poppiti RJ, Tan Y \& Agoulnik AI 2016 Constitutive notch signaling causes abnormal development of the oviducts, abnormal angiogenesis, and cyst formation in mouse female reproductive tract. Biology of Reproduction 94 67. (doi:10.1095/biolreprod.115.134569)

Ferris J, Mahboubi K, MacLusky N, King WA \& Favetta LA 2016 BPA exposure during in vitro oocyte maturation results in dose-dependent alterations to embryo development rates, apoptosis rate, sex ratio and gene expression. Reproductive Toxicology 59 128-138. (doi:10.1016) j.reprotox.2015.12.002)

Fischer B \& Bavister BD 1993 Oxygen tension in the oviduct and uterus of rhesus monkeys, hamsters and rabbits. Journal of Reproduction and Fertility 99 673-679. (doi:10.1530/jrf.0.0990673)

Flood PF, Jong A \& Betteridge KJ 1979 The location of eggs retained in the oviducts of mares. Journal of Reproduction and Fertility 57 291-294. (doi:10.1530/jrf.0.0570291)

Folmes CD \& Terzic A 2014 Metabolic determinants of embryonic development and stem cell fate. Reproduction Fertility and Development 27 82-88. (doi:10.1071/RD14383)

Freeman DA, Woods GL, Vanderwall DK \& Weber JA 1992 Embryo-initiated oviductal transport in mares. Journal of Reproduction and Fertility 95 535-538. (doi:10.1530/jrf.0.0950535)

Gaddum-Rosse P \& Blandau RJ 1973 In vitro studies on ciliary activity within the oviducts of the rabbit and pig. American Journal of Anatomy 136 91-104. (doi:10.1002/aja.1001360108)

Gaddum-Rosse P \& Blandau RJ 1976 Comparative observations on ciliary currents in mammalian oviducts. Biology of Reproduction 14 605-609. (doi:10.1095/biolreprod14.5.605)

Gandolfi F \& Moor RM 1987 Stimulation of early embryonic development in the sheep by co-culture with oviduct epithelial cells. Journal of Reproduction and Fertility 81 23-28. (doi:10.1530/ jrf.0.0810023)

Gardiner CS \& Reed DJ 1994 Status of glutathione during oxidant-induced oxidative stress in the preimplantation mouse embryo. Biology of Reproduction 51 1307-1314. (doi:10.1095/ biolreprod51.6.1307)

Gardiner CS, Salmen JJ, Brandt CJ \& Stover SK 1998 Glutathione is present in reproductive tract secretions and improves development of mouse embryos after chemically induced glutathione depletion. Biology of Reproduction 59 431-436. (doi:10.1095/biolreprod59.2.431)

Gardner DK \& Leese HJ 1990 Concentrations of nutrients in mouse oviduct fluid and their effects on embryo development and metabolism in vitro. Journal of Reproduction and Fertility 88 361-368. (doi:10.1530/jrf.0.0880361)

Gardner DK, Lane M, Calderon I \& Leeton J 1996 Environment of the preimplantation human embryo in vivo: metabolite analysis of oviduct and uterine fluids and metabolism of cumulus cells. Fertility and Sterility 65 349-353. (doi:10.1016/S0015-0282(16)58097-2)

Ge ZH \& Spicer SS 1988 Immunocytochemistry of ion transport mediators in the genital tract of female rodents. Biology of Reproduction 38 439-452. (doi:10.1095/biolreprod38.2.439)

Georgiou AS, Sostaric E, Wong CH, Snijders AP, Wright PC, Moore HD \& Fazeli A 2005 Gametes alter the oviductal secretory proteome. Molecular and Cellular Proteomics 4 1785-1796. (doi:10.1074/mcp. M500119-MCP200)

Gervasi MG, Osycka-Salut C, Caballero J, Vazquez-Levin M, Pereyra E, Billi S, Franchi A \& Perez-Martinez S 2011 Anandamide capacitates bull spermatozoa through CB1 and TRPV1 activation. PLOS ONE 6 e16993. (doi:10.1371/journal.pone.0016993)

Gervasi MG, Marczylo TH, Lam PM, Rana S, Franchi AM, Konje JC \& Perez-Martinez S 2013 Anandamide levels fluctuate in the bovine oviduct during the oestrous cycle. PLoS ONE 8 e72521. (doi:10.1371/ journal.pone.0072521)

Gervasi MG, Osycka-Salut C, Sanchez T, Alonso CA, Llados C, Castellano L, Franchi AM, Villalon M \& Perez-Martinez S 2016 Sperm release from the oviductal epithelium depends on $\mathrm{Ca}(2+)$ influx upon activation of CB1 and TRPV1 by anandamide. Journal of Cellular Biochemistry 117 320-333. (doi:10.1002/jcb.25273)

Gomes MV, Gomes CC, Pinto W Jr \& Ramos ES 2007 Methylation pattern at the KvDMR in a child with Beckwith-Wiedemann syndrome conceived by ICSI. American Journal of Medical Genetics Part A 143A 625-629. (doi:10.1002/ajmg.a.31628)

Gonzalez G \& Behringer RR 2009 Dicer is required for female reproductive tract development and fertility in the mouse. Molecular Reproduction and Development 76 678-688. (doi:10.1002/mrd.21010)

Gregoraszczuk EL, Cala M \& Witkowska E 2000 Glycogen distribution in porcine fallopian tube epithelium during the estrus cycle. Folia Biologica 48 85-90.

Griffiths GS, Miller KA, Galileo DS \& Martin-DeLeon PA 2008 Murine SPAM1 is secreted by the estrous uterus and oviduct in a form that can bind to sperm during capacitation: acquisition enhances hyaluronic acid-binding ability and cumulus dispersal efficiency. Reproduction 135 293-301. (doi:10.1530/REP-07-0340)

Grinsted J, Kjer JJ, Blendstrup K \& Pedersen JF 1985 Is low temperature of the follicular fluid prior to ovulation necessary for normal oocyte development? Fertility and Sterility 43 34-39. (doi:10.1016/S00150282(16)48314-7)

Groot PC, Mager WH, Henriquez NV, Pronk JC, Arwert F, Planta RJ, Eriksson AW \& Frants RR 1990 Evolution of the human alphaamylase multigene family through unequal, homologous, and inter- and intrachromosomal crossovers. Genomics 8 97-105. (doi:10.1016/0888-7543(90)90230-R)

Guerin P \& Menezo Y 1995 Hypotaurine and taurine in gamete and embryo environments: de novo synthesis via the cysteine sulfinic acid pathway in oviduct cells. Zygote 3 333-343. (doi:10.1017/ S0967199400002768)

Guerin P, Guillaud J \& Menezo Y 1995 Hypotaurine in spermatozoa and genital secretions and its production by oviduct epithelial cells in vitro. Human Reproduction 10 866-872.

Guerin P, El Mouatassim S \& Menezo Y 2001 Oxidative stress and protection against reactive oxygen species in the pre-implantation embryo and its surroundings. Human Reproduction Update 7 175-189. (doi:10.1093/humupd/7.2.175)

Guimaraes AL, Pereira SA, Kussano NR \& Dode MA 2016 The effect of pre-maturation culture using phosphodiesterase type 3 inhibitor and insulin, transferrin and selenium on nuclear and cytoplasmic maturation of bovine oocytes. Zygote 24 219-229. (doi:10.1017/ S0967199415000064)

Guo H, Zhu P, Yan L, Li R, Hu B, Lian Y, Yan J, Ren X, Lin S, Li J, et al. 2014 The DNA methylation landscape of human early embryos. Nature 511 606-610. (doi:10.1038/nature13544)

Guyader-Joly C, Guerin P, Renard JP, Guillaud J, Ponchon S \& Menezo Y 1998 Precursors of taurine in female genital tract: effects on developmental capacity of bovine embryo produced in vitro. Amino Acids 15 27-42. (doi:10.1007/BF01345278)

Haddad SN \& Wira CR 2014 Estradiol regulation of constitutive and keratinocyte growth factor-induced CCL20 and CXCL1 secretion by mouse uterine epithelial cells. American Journal of Reproductive Immunology 72 34-44. (doi:10.1111/aji.12260)

Halbert SA, Tam PY \& Blandau RJ 1976 Egg transport in the rabbit oviduct: the roles of cilia and muscle. Science 191 1052-1053. (doi:10.1126/science.1251215)

Halbert SA, Becker DR \& Szal SE 1989 Ovum transport in the rat oviductal ampulla in the absence of muscle contractility. Biology of Reproduction 40 1131-1136. (doi:10.1095/biolreprod40.6.1131)

Hammami S, Morato R, Romaguera R, Roura M, Catala MG, Paramio MT, Mogas T \& Izquierdo D 2013 Developmental competence and 
embryo quality of small oocytes from pre-pubertal goats cultured in IVM medium supplemented with low level of hormones, insulin-transferrin-selenium and ascorbic acid. Reproduction in Domestic Animals 48 339-344. (doi:10.1111/j.14390531.2012.02160.x)

Hamner CE \& Fox SB 1968 Effect of oestrogen and progesterone on physical properties of rabbit oviduct fluid. Journal of Reproduction and Fertility 16 121-122. (doi:10.1530/jrf.0.0160121)

Han L, Nishimura K, Sadat Al Hosseini H, Bianchi E, Wright GJ \& Jovine L 2016 Divergent evolution of vitamin B9 binding underlies Juno-mediated adhesion of mammalian gametes. Current Biology $\mathbf{2 6}$ R100-R101. (doi:10.1016/j.cub.2015.12.034)

Hansen JM \& Harris C 2015 Glutathione during embryonic development. Biochimica et Biophysica Acta 1850 1527-1542. (doi:10.1016/j. bbagen.2014.12.001)

Harvey MB, Arcellana-Panlilio MY, Zhang X, Schultz GA \& Watson AJ 1995 Expression of genes encoding antioxidant enzymes in preimplantation mouse and cow embryos and primary bovine oviduct cultures employed for embryo coculture. Biology of Reproduction 53 532-540. (doi:10.1095/biolreprod53.3.532)

Hayashi Y, Fukayama M, Koike M \& Nakayama T 1986 Amylase in human lungs and the female genital tract. Histochemical and immunohistochemical localization. Histochemistry 85 491-496. (doi:10.1007/BF00508431)

Hess AP, Talbi S, Hamilton AE, Baston-Buest DM, Nyegaard M, Irwin JC, Barragan F, Kruessel JS, Germeyer A \& Giudice LC 2013 The human oviduct transcriptome reveals an anti-inflammatory, anti-angiogenic, secretory and matrix-stable environment during embryo transit. Reproductive BioMedicine Online 27 423-435. (doi:10.1016/j.rbmo.2013.06.013)

Hiura H, Okae H, Chiba H, Miyauchi N, Sato F, Sato A \& Arima T 2014 Imprinting methylation errors in ART. Reproductive Medicine and Biology 13 193-202. (doi:10.1007/s12522-014-0183-3)

Hochberg CJ 1974 Tubal amylase. Obstetrics and Gynecology 43 129-131.

Huang Z \& Wells D 2010 The human oocyte and cumulus cells relationship: new insights from the cumulus cell transcriptome. Molecular Human Reproduction 16 715-725. (doi:10.1093/molehr/ gaq031)

Huang JC, Goldsby JS, Arbab F, Melhem Z, Aleksic N \& Wu KK 2004 Oviduct prostacyclin functions as a paracrine factor to augment the development of embryos. Human Reproduction 19 2907-2912. (doi:10.1093/humrep/deh520)

Huang N, Liu B, Dong Z, Mao W, Zhang N, Li C \& Cao J 2015 Prostanoid receptors $\mathrm{EP} 2, \mathrm{EP} 4$, and FP are regulated by estradiol in bovine oviductal smooth muscle. Prostaglandins \& Other Lipid Mediators 121 170-175. (doi:10.1016/j.prostaglandins.2015.08.002)

Hunt PA, Koehler KE, Susiarjo M, Hodges CA, Ilagan A, Voigt RC, Thomas S, Thomas BF \& Hassold TJ 2003 Bisphenol a exposure causes meiotic aneuploidy in the female mouse. Current Biology 13 546-553. (doi:10.1016/S0960-9822(03)00189-1)

Hunter RH 2012 Temperature gradients in female reproductive tissues. Reproductive BioMedicine Online 24 377-380. (doi:10.1016/ j.rbmo.2011.12.007)

Hunter RH, Bogh IB, Einer-Jensen N, Muller S \& Greve T 2000 Pre-ovulatory graafian follicles are cooler than neighbouring stroma in pig ovaries. Human Reproduction 15 273-283. (doi:10.1093/ humrep/15.2.273)

Imai H, Sumi D, Sakamoto H, Hanamoto A, Arai M, Chiba N \& Nakagawa Y 1996 Overexpression of phospholipid hydroperoxide glutathione peroxidase suppressed cell death due to oxidative damage in rat basophile leukemia cells (RBL-2H3). Biochemical and Biophysical Research Communications 222 432-438. (doi:10.1006/ bbrc.1996.0762)

Isobe T, Minoura H, Tanaka K, Shibahara T, Hayashi N \& Toyoda N 2002 The effect of RANTES on human sperm chemotaxis. Human Reproduction 17 1441-1446. (doi:10.1093/humrep/17.6.1441)
Jang HY, Ji SJ, Kim YH, Lee HY, Shin JS, Cheong HT, Kim JT, Park IC, Kong HS, Park CK, et al. 2010 Antioxidative effects of astaxanthin against nitric oxide-induced oxidative stress on cell viability and gene expression in bovine oviduct epithelial cell and the developmental competence of bovine IVM/IVF embryos. Reproduction in Domestic Animals 45 967-974. (doi:10.1111/j.1439-0531.2009.01469.x)

Jankovic SM, Varjacic M \& Protic B 2001 Relaxant effect of oxytocin on isolated human oviduct. Croatian Medical Journal 42 511-516.

Jones GM, Cram DS, Song B, Magli MC, Gianaroli L, Lacham-Kaplan O, Findlay JK, Jenkin G \& Trounson AO 2008 Gene expression profiling of human oocytes following in vivo or in vitro maturation. Human Reproduction 23 1138-1144. (doi:10.1093/humrep/den085)

Kane MT 1975 Bicarbonate requirements for culture of one-cell rabbit ova to blastocysts. Biology of Reproduction 12 552-555. (doi:10.1095/ biolreprod12.5.552)

Kessler M, Hoffmann K, Brinkmann V, Thieck O, Jackisch S, Toelle B, Berger H, Mollenkopf HJ, Mangler M, Sehouli J, et al. 2015 The Notch and Wnt pathways regulate stemness and differentiation in human fallopian tube organoids. Nature Communications 68989. (doi:10.1038/ncomms9989)

Khosla S, Dean W, Brown D, Reik W \& Feil R 2001 Culture of preimplantation mouse embryos affects fetal development and the expression of imprinted genes. Biology of Reproduction 64 918-926. (doi:10.1095/biolreprod64.3.918)

Kim SH, Cho KW, Kim SZ \& Koh GY 1997 Characterization of the atrial natriuretic peptide system in the oviduct. Endocrinology 138 2410-2416. (doi:10.1210/endo.138.6.5160)

Kobayashi Y, Yamamoto Y, Kageyama S, Hirayama H, Kimura K \& Okuda K 2016 Regulation of bovine oviductal NO synthesis by follicular steroids and prostaglandins. Reproduction 151 577-587. (doi:10.1530/REP-15-0254)

Kumaresan A, Gonzalez R, Johannisson A \& Berqvist AS 2014 Dynamic quantification of intracellular calcium and protein tyrosine phosphorylation in cryopreserved boar spermatozoa during short-time incubation with oviductal fluid. Theriogenology $\mathbf{8 2}$ 1145-1153. (doi:10.1016/j.theriogenology.2014.07.029)

Lam X, Gieseke C, Knoll M \& Talbot P 2000 Assay and importance of adhesive interaction between hamster (Mesocricetus auratus) oocyte-cumulus complexes and the oviductal epithelium. Biology of Reproduction 62 579-588. (doi:10.1095/biolreprod62.3.579)

Lapointe J, Kimmins S, Maclaren LA \& Bilodeau JF 2005 Estrogen selectively up-regulates the phospholipid hydroperoxide glutathione peroxidase in the oviducts. Endocrinology 146 2583-2592. (doi:10.1210/en.2004-1373)

Lazaraviciute G, Kauser M, Bhattacharya S, Haggarty P \& Bhattacharya S 2014 A systematic review and meta-analysis of DNA methylation levels and imprinting disorders in children conceived by IVF/ICSI compared with children conceived spontaneously. Human Reproduction Update 20 840-852. (doi:10.1093/humupd/dmu033)

Le Masson F \& Christians E 2011 HSFs and regulation of Hsp70.1 (Hspa1b) in oocytes and preimplantation embryos: new insights brought by transgenic and knockout mouse models. Cell Stress and Chaperones 16 275-285. (doi:10.1007/s12192-010-0239-1)

Leese HJ 1988 The formation and function of oviduct fluid. Journal of Reproduction and Fertility 82 843-856. (doi:10.1530/jrf.0.0820843)

Leese HJ 2012 Metabolism of the preimplantation embryo: 40 years on. Reproduction 143 417-427. (doi:10.1530/REP-11-0484)

Leese HJ, Conaghan J, Martin KL \& Hardy K 1993 Early human embryo metabolism. Bioessays 15 259-264. (doi:10.1002/bies.950150406)

Li TY, Colley D, Barr KJ, Yee SP \& Kidder GM 2007 Rescue of oogenesis in Cx37-null mutant mice by oocyte-specific replacement with Cx43. Journal of Cell Science 120 4117-4125. (doi:10.1242/jcs.03488)

Li HJ, Sutton-McDowall ML, Wang X, Sugimura S, Thompson JG \& Gilchrist RB 2016 Extending prematuration with cAMP modulators enhances the cumulus contribution to oocyte antioxidant defence

Published by Bioscientifica Ltd 
and oocyte quality via gap junctions. Human Reproduction $\mathbf{3 1}$ 810-821. (doi:10.1093/humrep/dew020)

Liao SB, Ho JC, Tang F \& O WS 2011 Adrenomedullin increases ciliary beat frequency and decreases muscular contraction in the rat oviduct. Reproduction 141 367-372. (doi:10.1530/REP-10-0230)

Liao SB, Cheung KH, Cheung MP, To YT, O WS \& Tang F 2013 Adrenomedullin increased the short-circuit current in the pig oviduct through chloride channels via the CGRP receptor: mediation by cAMP and calcium ions but not by nitric oxide. Biology of Reproduction 89 99. (doi:10.1095/biolreprod.113.109934)

Lindblom B, Wilhelmsson L, Wikland M, Hamberger L \& Wiqvist N 1983 Prostaglandins and oviductal function. Acta Obstetricia et Gynecologica Scandinavica Supplement 113 43-46. (doi:10.3109/00016348309155195)

Lindenbaum ES, Peretz BA \& Beach D 1983 Menstrual-cycle-dependent and -independent features of the human Fallopian tube fimbrial epithelium: an ultrastructural and cytochemical study. Gynecologic and Obstetric Investigation 16 76-85. (doi:10.1159/000299227)

Lippes J, Krasner J, Alfonso LA, Dacalos ED \& Lucero R 1981 Human oviductal fluid proteins. Fertility and Sterility 36 623-629. (doi:10.1016/S0015-0282(16)45861-9)

Lopera-Vasquez R, Hamdi M, Maillo V, Lloreda V, Coy P, Gutierrez-Adan A, Bermejo-Alvarez P \& Rizos D 2015 Effect of bovine oviductal fluid on development and quality of bovine embryos produced in vitro. Reproduction Fertility and Development. (doi:10.1071/ RD15238)

Lorenzo IM, Liedtke W, Sanderson MJ \& Valverde MA 2008 TRPV4 channel participates in receptor-operated calcium entry and ciliary beat frequency regulation in mouse airway epithelial cells. PNAS 105 12611-12616. (doi:10.1073/pnas.0803970105)

Lu YC, Yang J, Fok KL, Ye YH, Jin L, Chen ZY, Zhang XM, Huang HF \& Chan HC 2016 Involvement of $\mathrm{Cl}(-) / \mathrm{HCO} 3(-)$ exchanger SLC26A3 and SLC26A6 in preimplantation embryo cleavage. Scientific Reports 6 28402. (doi:10.1038/srep28402)

Lucas E 2013 Epigenetic effects on the embryo as a result of periconceptional environment and assisted reproduction technology. Reproductive BioMedicine Online 27 477-485. (doi:10.1016/j. rbmo.2013.06.003)

Luke B, Brown MB, Wantman E, Lederman A, Gibbons W, Schattman GL, Lobo RA, Leach RE \& Stern JE 2012 Cumulative birth rates with linked assisted reproductive technology cycles. New England Journal of Medicine 366 2483-2491. (doi:10.1056/ NEJMoa1110238)

Lutwak-Mann C 1955 Carbonic anhydrase in the female reproductive tract; occurrence, distribution and hormonal dependence. Journal of Endocrinology 13 26-38. (doi:10.1677/joe.0.0130026)

Lyons RA, Saridogan E \& Djahanbakhch O 2006 The reproductive significance of human Fallopian tube cilia. Human Reproduction Update 12 363-372. (doi:10.1093/humupd/dml012)

Ma JY, Liang XW, Schatten H \& Sun QY 2012 Active DNA demethylation in mammalian preimplantation embryos: new insights and new perspectives. Molecular Human Reproduction 18 333-340. (doi:10.1093/ molehr/gas014)

Maas DH, Storey BT \& Mastroianni L Jr 1977 Hydrogen ion and carbon dioxide content of the oviductal fluid of the rhesus monkey (Macaca mulatta). Fertility and Sterility 28 981-985. (doi:10.1016/ S0015-0282(16)42801-3)

Maher ER, Brueton LA, Bowdin SC, Luharia A, Cooper W, Cole TR, Macdonald F, Sampson JR, Barratt CL, Reik W, et al. 2003 Beckwith-Wiedemann syndrome and assisted reproduction technology (ART). Journal of Medical Genetics 40 62-64. (doi:10.1136/ jmg.40.1.62)

Mahmood T, Saridogan E, Smutna S, Habib AM \& Djahanbakhch O 1998 The effect of ovarian steroids on epithelial ciliary beat frequency in the human Fallopian tube. Human Reproduction 13 2991-2994. (doi:10.1093/humrep/13.11.2991)
Mann MR, Lee SS, Doherty AS, Verona RI, Nolen LD, Schultz RM \& Bartolomei MS 2004 Selective loss of imprinting in the placenta following preimplantation development in culture. Development 131 3727-3735. (doi:10.1242/dev.01241)

Mansour R, Ishihara O, Adamson GD, Dyer S, de Mouzon J, Nygren KG, Sullivan E \& Zegers-Hochschild F 2014 International committee for monitoring assisted reproductive technologies world report: assisted reproductive technology 2006. Human Reproduction 29 1536-1551. (doi:10.1093/humrep/deu084)

Marei WF, Salavati M \& Fouladi-Nashta AA 2013 Critical role of hyaluronidase-2 during preimplantation embryo development. Molecular Human Reproduction 19 590-599. (doi:10.1093/molehr/gat032)

Mariani ML, Ciocca DR, Gonzalez Jatuff AS \& Souto M 2003 Effect of neonatal chronic stress on expression of Hsp70 and oestrogen receptor alpha in the rat oviduct during development and the oestrous cycle. Reproduction 126 801-808. (doi:10.1530/ rep.0.1260801)

Mariani ML, Souto M, Fanelli MA \& Ciocca DR 2000 Constitutive expression of heat shock proteins hsp25 and hsp70 in the rat oviduct during neonatal development, the oestrous cycle and early pregnancy. Journal of Reproduction and Fertility 120 217-223. (doi:10.1530/reprod/120.2.217)

Marino JL, Moore VM, Willson KJ, Rumbold A, Whitrow MJ, Giles LC \& Davies MJ 2014 Perinatal outcomes by mode of assisted conception and sub-fertility in an Australian data linkage cohort. PLOS ONE 9 e80398. (doi:10.1371/journal.pone.0080398)

Marquez RT, Baggerly KA, Patterson AP, Liu J, Broaddus R, Frumovitz M, Atkinson EN, Smith DI, Hartmann L, Fishman D, et al. 2005 Patterns of gene expression in different histotypes of epithelial ovarian cancer correlate with those in normal fallopian tube, endometrium, and colon. Clinical Cancer Research 11 6116-6126. (doi:10.1158/ 1078-0432.CCR-04-2509)

Martin-Romero FJ, Miguel-Lasobras EM, Dominguez-Arroyo JA, Gonzalez-Carrera E \& Alvarez IS 2008 Contribution of culture media to oxidative stress and its effect on human oocytes. Reproductive BioMedicine Online 17 652-661. (doi:10.1016/S14726483(10)60312-4)

Mastroianni L Jr \& Jones R 1965 Oxygen tension within the rabbit fallopian tube. Journal of Reproduction and Fertility 9 99-102. (doi:10.1530/jrf.0.0090099)

Mc GR, Hargan LA, Potter BA \& Daus AT Jr 1958 Amylase in fallopian tubes. Proceedings of the Society for Experimental Biology and Medicine 99 130-131. (doi:10.3181/00379727-99-24270)

McDonald MF \& Bellve AR 1969 Influence of oestrogen and progesterone on flow of fluid from the Fallopian tube in the ovariectomized ewe. Journal of Reproduction and Fertility 20 51-61. (doi:10.1530/ jrf.0.0200051)

McLernon DJ, Maheshwari A, Lee AJ \& Bhattacharya S 2016 Cumulative live birth rates after one or more complete cycles of IVF: a population-based study of linked cycle data from 178,898 women. Human Reproduction 31 572-581. (doi:10.1093/humrep/dev336)

Messerschmidt DM, Knowles BB \& Solter D 2014 DNA methylation dynamics during epigenetic reprogramming in the germline and preimplantation embryos. Genes and Development 28 812-828. (doi:10.1101/gad.234294.113)

Miki K \& Clapham DE 2013 Rheotaxis guides mammalian sperm. Current Biology 23 443-452. (doi:10.1016/j.cub.2013.02.007)

Mondejar I, Martinez-Martinez I, Aviles M \& Coy P 2013 Identification of potential oviductal factors responsible for zona pellucida hardening and monospermy during fertilization in mammals. Biology of Reproduction 89 67. (doi:10.1095/biolreprod.113.111385)

Morales P, Palma V, Salgado AM \& Villalon M 1996 Sperm interaction with human oviductal cells in vitro. Human Reproduction 11 1504-1509. (doi:10.1093/oxfordjournals.humrep.a019426)

Motta PM, Nottola SA, Makabe S \& Heyn R 2000 Mitochondrial morphology in human fetal and adult female germ cells. Human

Published by Bioscientifica Ltd. 
Reproduction 15 (Supplement 2) 129-147. (doi:10.1093/humrep/ 15.suppl_2.129)

Nagaraja AK, Andreu-Vieyra C, Franco HL, Ma L, Chen R, Han DY, Zhu H, Agno JE, Gunaratne PH, DeMayo FJ, et al. 2008 Deletion of Dicer in somatic cells of the female reproductive tract causes sterility. Molecular Endocrinology 22 2336-2352. (doi:10.1210/ me.2008-0142)

Nakahari T, Nishimura A, Shimamoto C, Sakai A, Kuwabara H, Nakano T, Tanaka S, Kohda Y, Matsumura H \& Mori H 2011 The regulation of ciliary beat frequency by ovarian steroids in the guinea pig Fallopian tube: interactions between oestradiol and progesterone. Biomedical Research 32 321-328. (doi:10.2220/biomedres.32.321)

Nasr-Esfahani MH \& Johnson MH 1992 How does transferrin overcome the in vitro block to development of the mouse preimplantation embryo? Journal of Reproduction and Fertility 96 41-48. (doi:10.1530/ jrf.0.0960041)

Nastri CO, Nobrega BN, Teixeira DM, Amorim J, Diniz LM, Barbosa MW, Giorgi VS, Pileggi VN \& Martins WP 2016 Low versus atmospheric oxygen tension for embryo culture in assisted reproduction: a systematic review and meta-analysis. Fertility and Sterility 106 95.e117-104.e117. (doi:10.1016/j.fertnstert.2016.02.037)

Ng A, Tan S, Singh G, Rizk P, Swathi Y, Tan TZ, Huang RY, Leushacke M \& Barker N 2014 Lgr5 marks stem/progenitor cells in ovary and tubal epithelia. Nature Cell Biology 16 745-757. (doi:10.1038/ncb3000)

Nichol R, Hunter RH, Gardner DK, Leese HJ \& Cooke GM 1992 Concentrations of energy substrates in oviductal fluid and blood plasma of pigs during the peri-ovulatory period. Journal of Reproduction and Fertility 96 699-707. (doi:10.1530/jrf.0.0960699)

Nieder GL \& Corder CN 1982 Quantitative histochemical measurement of pyruvate and lactate in mouse oviduct during the estrous cycle. Journal of Histochemistry and Cytochemistry 30 1051-1058. (doi:10.1177/30.10.6890080)

Nieder GL \& Corder CN 1983 Pyruvate and lactate levels in oviducts of cycling, pregnant, and pseudopregnant mice. Biology of Reproduction 28 566-574. (doi:10.1095/biolreprod28.3.566)

Ning N, Zhu J, Du Y, Gao X, Liu C \& Li J 2014 Dysregulation of hydrogen sulphide metabolism impairs oviductal transport of embryos. Nature Communications 5 4107. (doi:10.1038/ncomms5107)

Niwa S, Nakajima K, Miki H, Minato Y, Wang D \& Hirokawa N 2012 KIF19A is a microtubule-depolymerizing kinesin for ciliary length control. Developmental Cell 23 1167-1175. (doi:10.1016/j. devcel.2012.10.016)

Noreikat K, Wolff M, Kummer W \& Kolle S 2012 Ciliary activity in the oviduct of cycling, pregnant, and muscarinic receptor knockout mice. Biology of Reproduction 86 120. (doi:10.1095/biolreprod.111.096339)

Nozawa YI, Yao E, Lin C, Yang JH, Wilson CW, Gacayan R \& Chuang PT 2013 Fused (Stk36) is a ciliary protein required for central pair assembly and motile cilia orientation in the mammalian oviduct. Developmental Dynamics 242 1307-1319. (doi:10.1002/dvdy.24024)

O'Doherty AM, Di Fenza M \& Kolle S 2016 Lipopolysaccharide (LPS) disrupts particle transport, cilia function and sperm motility in an ex vivo oviduct model. Scientific Reports 6 24583. (doi:10.1038/ srep24583)

Oberst FW \& Plass ED 1936 The hydrogen ion concentration of human vaginal discharge. American Journal of Obstetrics and Gynecology 32 22-35. (doi:10.1016/S0002-9378(15)31872-X)

Odor DL, Gaddum-Rosse P \& Rumery RE 1983 Secretory cells of the oviduct of the pig-tailed monkey, Macaca nemestrina, during the menstrual cycle and after estrogen treatment. American Journal of Anatomy 166 149-172. (doi:10.1002/aja.1001660203)

Okae H, Chiba H, Hiura H, Hamada H, Sato A, Utsunomiya T, Kikuchi H, Yoshida H, Tanaka A, Suyama M, et al. 2014 Genome-wide analysis of DNA methylation dynamics during early human development. PLoS Genetics 10 e1004868. (doi:10.1371/journal.pgen.1004868)

Okamoto Y, Yoshida N, Suzuki T, Shimozawa N, Asami M, Matsuda T, Kojima N, Perry AC \& Takada T 2016 DNA methylation dynamics in mouse preimplantation embryos revealed by mass spectrometry. Scientific Reports 6 19134. (doi:10.1038/srep19134)

Olson JH \& Chandler DE 1999 Xenopus laevis egg jelly contains small proteins that are essential to fertilization. Developmental Biology $\mathbf{2 1 0}$ 401-410. (doi:10.1006/dbio.1999.9281)

Olson JH, Xiang X, Ziegert T, Kittelson A, Rawls A, Bieber AL \& Chandler DE 2001 Allurin, a 21-kDa sperm chemoattractant from Xenopus egg jelly, is related to mammalian sperm-binding proteins. PNAS 98 11205-11210. (doi:10.1073/pnas.211316798)

Oren-Benaroya R, Orvieto R, Gakamsky A, Pinchasov M \& Eisenbach M 2008 The sperm chemoattractant secreted from human cumulus cells is progesterone. Human Reproduction 23 2339-2345. (doi:10.1093/ humrep/den265)

Orihuela PA \& Croxatto HB 2001 Acceleration of oviductal transport of oocytes induced by estradiol in cycling rats is mediated by nongenomic stimulation of protein phosphorylation in the oviduct. Biology of Reproduction 65 1238-1245. (doi:10.1095/ biolreprod65.4.1238)

Orihuela PA, Rios M \& Croxatto HB 2001 Disparate effects of estradiol on egg transport and oviductal protein synthesis in mated and cyclic rats. Biology of Reproduction 65 1232-1237. (doi:10.1095/ biolreprod65.4.1232)

Orihuela PA, Parada-Bustamante A, Cortes PP, Gatica C \& Croxatto HB 2003 Estrogen receptor, cyclic adenosine monophosphate, and protein kinase A are involved in the nongenomic pathway by which estradiol accelerates oviductal oocyte transport in cyclic rats. Biology of Reproduction 68 1225-1231. (doi:10.1095/biolreprod.102.011395)

Orihuela PA, Parada-Bustamante A, Zuniga LM \& Croxatto HB 2006 Inositol triphosphate participates in an oestradiol nongenomic signalling pathway involved in accelerated oviductal transport in cycling rats. Journal of Endocrinology 188 579-588. (doi:10.1677/ joe.1.06448)

Ortiz ME, Bedregal P, Carvajal MI \& Croxatto HB 1986 Fertilized and unfertilized ova are transported at different rates by the hamster oviduct. Biology of Reproduction 34 777-781. (doi:10.1095/ biolreprod34.4.777)

Osycka-Salut C, Gervasi MG, Pereyra E, Cella M, Ribeiro ML, Franchi AM \& Perez-Martinez S 2012 Anandamide induces sperm release from oviductal epithelia through nitric oxide pathway in bovines. PLoS ONE 7 e30671. (doi:10.1371/journal.pone.0030671)

Overstreet JW \& Cooper GW 1978a Sperm transport in the reproductive tract of the female rabbit: I. The rapid transit phase of transport. Biology of Reproduction 19 101-114. (doi:10.1095/biolreprod19.1.101)

Overstreet JW \& Cooper GW 1978b Sperm transport in the reproductive tract of the female rabbit: II. The sustained phase of transport. Biology of Reproduction 19 115-132. (doi:10.1095/biolreprod19.1.115)

Owen CM \& Segars JH Jr 2009 Imprinting disorders and assisted reproductive technology. Seminars in Reproductive Medicine $\mathbf{2 7}$ 417-428. (doi:10.1055/s-0029-1237430)

Paik DY, Janzen DM, Schafenacker AM, Velasco VS, Shung MS, Cheng D, Huang J, Witte ON \& Memarzadeh S 2012 Stem-like epithelial cells are concentrated in the distal end of the fallopian tube: a site for injury and serous cancer initiation. Stem Cells 30 2487-2497. (doi:10.1002/stem.1207)

Pandey S, Shetty A, Hamilton M, Bhattacharya S \& Maheshwari A 2012 Obstetric and perinatal outcomes in singleton pregnancies resulting from IVF/ICSI: a systematic review and meta-analysis. Human Reproduction Update 18 485-503. (doi:10.1093/humupd/dms018)

Paria BC \& Dey SK 1990 Preimplantation embryo development in vitro: cooperative interactions among embryos and role of growth factors. PNAS 87 4756-4760. (doi:10.1073/pnas.87.12.4756)

Parr BA \& McMahon AP 1998 Sexually dimorphic development of the mammalian reproductive tract requires Wnt-7a. Nature 395 707-710. (doi:10.1038/27221)

Pelton TA, Bettess MD, Lake J, Rathjen J \& Rathjen PD 1998 Developmental complexity of early mammalian pluripotent cell 
populations in vivo and in vitro. Reproduction Fertility and Development 10 535-549. (doi:10.1071/RD98084)

Perez-Cerezales S, Boryshpolets S, Afanzar O, Brandis A, Nevo R, Kiss V \& Eisenbach M 2015 Involvement of opsins in mammalian sperm thermotaxis. Scientific Reports 5 16146. (doi:10.1038/srep16146)

Pfeifer TL \& Chegini N 1994 Immunohistochemical localization of insulin-like growth factor (IGF-I), IGF-I receptor, and IGF binding proteins 1-4 in human fallopian tube at various reproductive stages. Biology of Reproduction 50 281-289. (doi:10.1095/biolreprod50.2.281)

Pike IL, Murdoch RN \& Wales RG 1975 The incorporation of carbon dioxide into the major classes of RNA during culture of the preimplantation mouse embryo. Journal of Reproduction and Fertility 45 211-226. (doi:10.1530/jrf.0.0450211)

Pinborg A, Wennerholm UB, Romundstad LB, Loft A, Aittomaki K, Soderstrom-Anttila V, Nygren KG, Hazekamp J \& Bergh C 2013 Why do singletons conceived after assisted reproduction technology have adverse perinatal outcome? Systematic review and meta-analysis. Human Reproduction Update 19 87-104. (doi:10.1093/humupd/dms044)

Pollard JW, Plante C, King WA, Hansen PJ, Betteridge KJ \& Suarez SS 1991 Fertilizing capacity of bovine sperm may be maintained by binding of oviductal epithelial cells. Biology of Reproduction 44 102-107. (doi:10.1095/biolreprod44.1.102)

Prunskaite-Hyyrylainen R, Skovorodkin I, Xu Q, Miinalainen I, Shan J \& Vainio SJ 2016 Wnt4 coordinates directional cell migration and extension of the Mullerian duct essential for ontogenesis of the female reproductive tract. Human Molecular Genetics 25 1059-1073. (doi:10.1093/hmg/ddv621)

Punamaki RL, Tiitinen A, Lindblom J, Unkila-Kallio L, Flykt M, Vanska M, Poikkeus P \& Tulppala M 2016 Mental health and developmental outcomes for children born after ART: a comparative prospective study on child gender and treatment type. Human Reproduction $\mathbf{3 1}$ 100-107. (doi:10.1093/humrep/dev273)

Quill TA, Sugden SA, Rossi KL, Doolittle LK, Hammer RE \& Garbers DL 2003 Hyperactivated sperm motility driven by CatSper 2 is required for fertilization. PNAS 100 14869-14874. (doi:10.1073/ pnas.2136654100)

Quinn P \& Wales RG 1974 Fixation of carbon dioxide by preimplantation rabbit embryos in vitro. Journal of Reproduction and Fertility 36 29-39. (doi:10.1530/jrf.0.0360029)

Redgrove KA, Nixon B, Baker MA, Hetherington L, Baker G, Liu DY \& Aitken RJ 2012 The molecular chaperone HSPA2 plays a key role in regulating the expression of sperm surface receptors that mediate sperm-egg recognition. PLoS ONE 7 e50851. (doi:10.1371/journal. pone.0050851)

Redgrove KA, Anderson AL, McLaughlin EA, O'Bryan MK, Aitken RJ \& Nixon B 2013 Investigation of the mechanisms by which the molecular chaperone HSPA2 regulates the expression of sperm surface receptors involved in human sperm-oocyte recognition. Molecular Human Reproduction 19 120-135. (doi:10.1093/molehr/gas064)

Reik W, Romer I, Barton SC, Surani MA, Howlett SK \& Klose J 1993 Adult phenotype in the mouse can be affected by epigenetic events in the early embryo. Development 119 933-942.

Reik W, Dean W \& Walter J 2001 Epigenetic reprogramming in mammalian development. Science 293 1089-1093. (doi:10.1126/ science.1063443)

Ren D, Navarro B, Perez G, Jackson AC, Hsu S, Shi Q, Tilly JL \& Clapham DE 2001 A sperm ion channel required for sperm motility and male fertility. Nature $\mathbf{4 1 3}$ 603-609. (doi:10.1038/35098027)

Reuquen P, Orostica ML, Rojas I, Diaz P, Parada-Bustamante A \& Orihuela PA 2015 Estradiol increases IP3 by a nongenomic mechanism in the smooth muscle cells from the rat oviduct. Reproduction 150 331-341. (doi:10.1530/REP-15-0137)

Rotem R, Zamir N, Keynan N, Barkan D, Breitbart H \& Naor Z 1998 Atrial natriuretic peptide induces acrosomal exocytosis of human spermatozoa. American Journal of Physiology 274 E218-E223.
Sakkas D \& Trounson AO 1990 Co-culture of mouse embryos with oviduct and uterine cells prepared from mice at different days of pseudopregnancy. Journal of Reproduction and Fertility 90 109-118. (doi:10.1530/jrf.0.0900109)

Salmen JJ, Skufca F, Matt A, Gushansky G, Mason A \& Gardiner CS 2005 Role of glutathione in reproductive tract secretions on mouse preimplantation embryo development. Biology of Reproduction $\mathbf{7 3}$ 308-314. (doi:10.1095/biolreprod.104.038307)

Sathananthan AH \& Trounson AO 2000 Mitochondrial morphology during preimplantational human embryogenesis. Human Reproduction 15 (Supplement 2) 148-159. (doi:10.1093/humrep/15.suppl_2.148)

Schultka R \& Cech S 1989 Demonstration of glycogen in human oviduct epithelium. Acta Histochemica 87 137-139. (doi:10.1016/S00651281(89)80016-9)

Shaeib F, Banerjee J, Maitra D, Diamond MP \& Abu-Soud HM 2013 Impact of hydrogen peroxide-driven Fenton reaction on mouse oocyte quality. Free Radical Biology and Medicine 58 154-159. (doi:10.1016/j.freeradbiomed.2012.12.007)

Shaeib F, Khan SN, Ali I, Thakur M, Saed MG, Dai J, Awonuga AO, Banerjee J \& Abu-Soud HM 2016 The defensive role of cumulus cells against reactive oxygen species insult in metaphase II mouse oocytes. Reproductive Sciences 23 498-507. (doi:10.1177/1933719115607993)

Shi W \& Haaf T 2002 Aberrant methylation patterns at the two-cell stage as an indicator of early developmental failure. Molecular Reproduction and Development 63 329-334. (doi:10.1002/mrd.90016)

Shi D, Komatsu K, Hirao M, Toyooka Y, Koyama H, Tissir F, Goffinet AM, Uemura T \& Fujimori T 2014 Celsr 1 is required for the generation of polarity at multiple levels of the mouse oviduct. Development 141 4558-4568. (doi:10.1242/dev.115659)

Simon AM, Goodenough DA, Li E \& Paul DL 1997 Female infertility in mice lacking connexin 37 . Nature 385 525-529. (doi:10.1038/385525a0)

Smilinich NJ, Day CD, Fitzpatrick GV, Caldwell GM, Lossie AC, Cooper PR, Smallwood AC, Joyce JA, Schofield PN, Reik W, et al. 1999 A maternally methylated CpG island in KvLQT1 is associated with an antisense paternal transcript and loss of imprinting in Beckwith-Wiedemann syndrome. PNAS 96 8064-8069. (doi:10.1073/ pnas.96.14.8064)

Smith TT \& Nothnick WB 1997 Role of direct contact between spermatozoa and oviductal epithelial cells in maintaining rabbit sperm viability. Biology of Reproduction 56 83-89. (doi:10.1095/ biolreprod56.1.83)

Smith ZD, Chan MM, Mikkelsen TS, Gu H, Gnirke A, Regev A \& Meissner A 2012 A unique regulatory phase of DNA methylation in the early mammalian embryo. Nature 484 339-344. (doi:10.1038/ nature10960)

Smith ZD, Chan MM, Humm KC, Karnik R, Mekhoubad S, Regev A, Eggan K \& Meissner A 2014 DNA methylation dynamics of the human preimplantation embryo. Nature 511 611-615. (doi:10.1038/ nature13581)

Snegovskikh V, Mutlu L, Massasa E \& Taylor HS 2014 Identification of putative fallopian tube stem cells. Reproductive Sciences 21 1460-1464. (doi:10.1177/1933719114553448)

Song S, Ghosh J, Mainigi M, Turan N, Weinerman R, Truongcao M, Coutifaris C \& Sapienza C 2015 DNA methylation differences between in vitro- and in vivo-conceived children are associated with ART procedures rather than infertility. Clinical Epigenetics $\mathbf{7} 41$. (doi:10.1186/s13148-015-0071-7)

Spilman CH \& Harper MJ 1975 Effects of prostaglandins on oviductal motility and egg transport. Gynecologic and Obstetric Investigation 6 186-205. (doi:10.1159/000301516)

Stern JE, Goldman MB, Hatasaka H, MacKenzie TA, Surrey ES, Racowsky C \& Society for Assisted Reproductive Technology Writing Group 2009 Optimizing the number of cleavage stage embryos to transfer on day 3 in women 38 years of age and older: a Society for 
Assisted Reproductive Technology database study. Fertility and Sterility 91 767-776. (doi:10.1016/j.fertnstert.2007.12.051)

Stewart CA \& Behringer RR 2012 Mouse oviduct development. Results and Problems in Cell Differentiation 55 247-262. (doi:10.1007/978-3-64230406-4_14)

Sturmey RG, Reis A, Leese HJ \& McEvoy TG 2009 Role of fatty acids in energy provision during oocyte maturation and early embryo development. Reproduction in Domestic Animals 44 (Supplement 3) 50-58. (doi:10.1111/j.1439-0531.2009.01402.x)

Suarez SS 2016 Mammalian sperm interactions with the female reproductive tract. Cell and Tissue Research 363 185-194. (doi:10.1007/s00441-015-2244-2)

Suarez SS \& Pacey AA 2006 Sperm transport in the female reproductive tract. Human Reproduction Update 12 23-37. (doi:10.1093/humupd/ dmi047)

Suarez SS, Katz DF, Owen DH, Andrew JB \& Powell RL 1991 Evidence for the function of hyperactivated motility in sperm. Biology of Reproduction 44 375-381. (doi:10.1095/biolreprod44.2.375)

Suarez SS, Dai XB, DeMott RP, Redfern K \& Mirando MA 1992 Movement characteristics of boar sperm obtained from the oviduct or hyperactivated in vitro. Journal of Andrology 13 75-80.

Subbanna S, Shivakumar M, Psychoyos D, Xie S \& Basavarajappa BS 2013 Anandamide-CB1 receptor signaling contributes to postnatal ethanol-induced neonatal neurodegeneration, adult synaptic, and memory deficits. Journal of Neuroscience 33 6350-6366. (doi:10.1523/ JNEUROSCI.3786-12.2013)

Sun X, Terakawa J, Clevers H, Barker N, Daikoku T \& Dey SK 2014 Ovarian LGR5 is critical for successful pregnancy. FASEB Journal 28 2380-2389. (doi:10.1096/fj.13-248344)

Sutton ML, Gilchrist RB \& Thompson JG 2003 Effects of in-vivo and in-vitro environments on the metabolism of the cumulus-oocyte complex and its influence on oocyte developmental capacity. Human Reproduction Update 9 35-48. (doi:10.1093/humupd/ dmg009)

Sutton-McDowall ML, Gilchrist RB \& Thompson JG 2010 The pivotal role of glucose metabolism in determining oocyte developmental competence. Reproduction 139 685-695. (doi:10.1530/REP-09-0345)

Sutton-McDowall ML, Feil D, Robker RL, Thompson JG \& Dunning KR 2012 Utilization of endogenous fatty acid stores for energy production in bovine preimplantation embryos. Theriogenology $\mathbf{7 7}$ 1632-1641. (doi:10.1016/j.theriogenology.2011.12.008)

Takeuchi K, Nagata Y, Sandow BA \& Hodgen GD 1992 Primary culture of human fallopian tube epithelial cells and co-culture of early mouse pre-embryos. Molecular Reproduction and Development 32 236-242. (doi:10.1002/mrd.1080320308)

Talo A 1991 How the myosalpinx works in gamete and embryo transport. Archivos de Biología y Medicina Experimentales 24 361-375.

Tanghe S, Van Soom A, Nauwynck H, Coryn M \& de Kruif A 2002 Minireview: functions of the cumulus oophorus during oocyte maturation, ovulation, and fertilization. Molecular Reproduction and Development 61 414-424. (doi:10.1002/mrd.10102)

Tay JI, Rutherford AJ, Killick SR, Maguiness SD, Partridge RJ \& Leese HJ 1997 Human tubal fluid: production, nutrient composition and response to adrenergic agents. Human Reproduction 12 2451-2456. (doi:10.1093/humrep/12.11.2451)

Teilmann SC, Byskov AG, Pedersen PA, Wheatley DN, Pazour GJ \& Christensen ST 2005 Localization of transient receptor potential ion channels in primary and motile cilia of the female murine reproductive organs. Molecular Reproduction and Development 71 444-452. (doi:10.1002/mrd.20312)

Teilmann SC, Clement CA, Thorup J, Byskov AG \& Christensen ST 2006 Expression and localization of the progesterone receptor in mouse and human reproductive organs. Journal of Endocrinology 191 525-535. (doi:10.1677/joe.1.06565)

Tenore JL 2000 Ectopic pregnancy. American Family Physician 61 1080-1088.
Teves ME, Barbano F, Guidobaldi HA, Sanchez R, Miska W \& Giojalas LC 2006 Progesterone at the picomolar range is a chemoattractant for mammalian spermatozoa. Fertility and Sterility 86 745-749. (doi:10.1016/j.fertnstert.2006.02.080)

Tosti E \& Menezo Y 2016 Gamete activation: basic knowledge and clinical applications. Human Reproduction Update 22 420-439. (doi:10.1093/humupd/dmw014)

Trimarchi JR, Liu L, Porterfield DM, Smith PJ \& Keefe DL 2000 Oxidative phosphorylation-dependent and -independent oxygen consumption by individual preimplantation mouse embryos. Biology of Reproduction 62 1866-1874. (doi:10.1095/biolreprod62.6.1866)

Tung CK, Hu L, Fiore AG, Ardon F, Hickman DG, Gilbert RO, Suarez SS \& Wu M 2015 Microgrooves and fluid flows provide preferential passageways for sperm over pathogen Tritrichomonas foetus. PNAS 112 5431-5436. (doi:10.1073/pnas.1500541112)

Varayoud J, Ramos JG, Bosquiazzo VL, Lower M, Munoz-de-Toro M \& Luque EH 2011 Neonatal exposure to bisphenol A alters rat uterine implantation-associated gene expression and reduces the number of implantation sites. Endocrinology 152 1101-1111. (doi:10.1210/ en.2009-1037)

Ventura-Junca P, Irarrazaval I, Rolle AJ, Gutierrez JI, Moreno RD \& Santos MJ 2015 In vitro fertilization (IVF) in mammals: epigenetic and developmental alterations. Scientific and bioethical implications for IVF in humans. Biological Research 48 68. (doi:10.1186/s40659015-0059-y)

Vieira GC, Chockalingam S, Melegh Z, Greenhough A, Malik S, Szemes M, Park JH, Kaidi A, Zhou L, Catchpoole D, et al. 2015 LGR5 regulates pro-survival MEK/ERK and proliferative Wnt/beta-catenin signalling in neuroblastoma. Oncotarget 6 40053-40067. (doi:10.18632/oncotarget.5548)

Villalon M, Ortiz ME, Aguayo C, Munoz J \& Croxatto HB 1982 Differential transport of fertilized and unfertilized ova in the rat. Biology of Reproduction 26 337-341. (doi:10.1095/biolreprod26.2.337)

Virant-Klun I, Knez K, Tomazevic T \& Skutella T 2013 Gene expression profiling of human oocytes developed and matured in vivo or in vitro. BioMed Research International 2013879489. (doi:10.1155/2013/879489)

Vishwakarma P 1962 The $\mathrm{pH}$ and bicarbonate-ion content of the oviduct and uterine fluids. Fertility and Sterility 13 481-485. (doi:10.1016/ S0015-0282(16)34633-7)

Vitaioli L, Gobbetti A \& Baldoni E 1996 Arylsulphatase A activity and sulphatide concentration in the female rabbit oviduct are under physiological hormonal influence. Histochemical Journal 28 149-156. (doi:10.1007/BF02331420)

Vlad M, Walker D \& Kennedy RC 1996 Nuclei number in human embryos co-cultured with human ampullary cells. Human Reproduction 11 1678-1686. (doi:10.1093/oxfordjournals.humrep. a019469)

Wang H, Guo Y, Wang D, Kingsley PJ, Marnett LJ, Das SK, DuBois RN \& Dey SK 2004 Aberrant cannabinoid signaling impairs oviductal transport of embryos. Nature Medicine 10 1074-1080. (doi:10.1038/ nm1104)

Wang N, Le F, Zhan QT, Li L, Dong MY, Ding GL, Xu CM, Jiang SW, Huang HF \& Jin F 2010 Effects of in vitro maturation on histone acetylation in metaphase II oocytes and early cleavage embryos. Obstetrics and Gynecology International 2010989278. (doi:10.1155/2010/989278)

Wanggren K, Lalitkumar PG, Stavreus-Evers A, Stabi B \& Gemzell-Danielsson K 2006 Prostaglandin E2 and F2alpha receptors in the human Fallopian tube before and after mifepristone treatment. Molecular Human Reproduction 12 577-585. (doi:10.1093/ molehr/gal058)

Wanggren K, Stavreus-Evers A, Olsson C, Andersson E \& Gemzell-Danielsson K 2008 Regulation of muscular contractions in the human Fallopian tube through prostaglandins and progestagens. Human Reproduction 23 2359-2368. (doi:10.1093/humrep/den260)

Published by Bioscientifica Ltd. 
Ward GE, Brokaw CJ, Garbers DL \& Vacquier VD 1985 Chemotaxis of Arbacia punctulata spermatozoa to resact, a peptide from the egg jelly layer. Journal of Cell Biology 101 2324-2329. (doi:10.1083/ jcb.101.6.2324)

Weber JA, Freeman DA, Vanderwall DK \& Woods GL 1991a Prostaglandin E2 hastens oviductal transport of equine embryos. Biology of Reproduction 45 544-546. (doi:10.1095/biolreprod45.4.544)

Weber JA, Freeman DA, Vanderwall DK \& Woods GL $1991 b$ Prostaglandin E2 secretion by oviductal transport-stage equine embryos. Biology of Reproduction 45 540-543. (doi:10.1095/ biolreprod45.4.540)

Wen S, Cao G, Bao T, Cheng L, Li H, Du C, Tu Y, Li Q, Jian R, Zhao P, et al. 2012 Modulation of ovine SBD-1 expression by 17beta-estradiol in ovine oviduct epithelial cells. BMC Veterinary Research 8143. (doi:10.1186/1746-6148-8-143)

White KL, Hehnke K, Rickords LF, Southern LL, Thompson DL Jr \& Wood TC 1989 Early embryonic development in vitro by coculture with oviductal epithelial cells in pigs. Biology of Reproduction 41 425-430. (doi:10.1095/biolreprod41.3.425)

Wijayagunawardane MP, Miyamoto A, Taquahashi Y, Gabler C, Acosta TJ, Nishimura M, Killian G \& Sato K 2001 In vitro regulation of local secretion and contraction of the bovine oviduct: stimulation by luteinizing hormone, endothelin-1 and prostaglandins, and inhibition by oxytocin. Journal of Endocrinology 168 117-130. (doi:10.1677/joe.0.1680117)

Winuthayanon W, Bernhardt ML, Padilla-Banks E, Myers PH, Edin ML, Hewitt SC, Korach KS \& Williams CJ 2015 Oviductal estrogen receptor alpha signaling prevents protease-mediated embryo death. eLife $\mathbf{4}$ e10453. (doi:10.7554/eLife.10453)

Wira CR, Fahey JV, Sentman CL, Pioli PA \& Shen L 2005 Innate and adaptive immunity in female genital tract: cellular responses and interactions. Immunological Reviews 206 306-335. (doi:10.1111/ j.0105-2896.2005.00287.x)

Wu J, Bao J, Kim M, Yuan S, Tang C, Zheng H, Mastick GS, Xu C \& Yan W 2014 Two miRNA clusters, miR-34b/c and miR-449, are essential for normal brain development, motile ciliogenesis, and spermatogenesis. PNAS 111 E2851-E2857. (doi:10.1073/pnas.1407777111)

Wydooghe E, Heras S, Dewulf J, Piepers S, Van den Abbeel E, De Sutter P, Vandaele L \& Van Soom A 2014 Replacing serum in culture medium with albumin and insulin, transferrin and selenium is the key to successful bovine embryo development in individual culture. Reproduction Fertility and Development 26 717-724. (doi:10.1071/ RD13043)
Xie M, McCoski SR, Johnson SE, Rhoads ML \& Ealy AD 2015 Combinatorial effects of epidermal growth factor, fibroblast growth factor 2 and insulin-like growth factor 1 on trophoblast cell proliferation and embryogenesis in cattle. Reproduction Fertility and Development. (doi:10.1071/RD15226)

Xu JS, Lee YL, Lee KF, Kwok KL, Lee WM, Luk JM \& Yeung WS 2004 Embryotrophic factor-3 from human oviductal cells enhances proliferation, suppresses apoptosis and stimulates the expression of the beta1 subunit of sodium-potassium ATPase in mouse embryos. Human Reproduction 19 2919-2926. (doi:10.1093/humrep/deh497)

Yang Y, Xu Y, Ding C, Khoudja RY, Lin M, Awonuga AO, Dai J, Puscheck EE, Rappolee DA \& Zhou C 2016 Comparison of 2, 5, and $20 \% \mathrm{O}_{2}$ on the development of post-thaw human embryos. Journal of Assisted Reproduction and Genetics 33 919-927. (doi:10.1007/ s10815-016-0693-5)

Ye J, Coleman J, Hunter MG, Craigon J, Campbell KH \& Luck MR 2007 Physiological temperature variants and culture media modify meiotic progression and developmental potential of pig oocytes in vitro. Reproduction 133 877-886. (doi:10.1530/REP-06-0318)

Yedwab GA, Paz G, Homonnai TZ, David MP \& Kraicer PF 1976 The temperature, $\mathrm{pH}$, and partial pressure of oxygen in the cervix and uterus of women and uterus of rats during the cycle. Fertility and Sterility 27 304-309. (doi:10.1016/S0015-0282(16)41722-X)

Yeung WS, Ho PC, Lau EY \& Chan ST 1992 Improved development of human embryos in vitro by a human oviductal cell co-culture system. Human Reproduction 7 1144-1149.

Yin N, Yao X, Qin Z, Wang YL \& Faiola F 2015 Assessment of Bisphenol A (BPA) neurotoxicity in vitro with mouse embryonic stem cells. Journal of Environmental Sciences 36 181-187. (doi:10.1016/j.jes.2015.06.004)

Zamir N, Riven-Kreitman R, Manor M, Makler A, Blumberg S, Ralt D \& Eisenbach M 1993 Atrial natriuretic peptide attracts human spermatozoa in vitro. Biochemical and Biophysical Research Communications 197 116-122. (doi:10.1006/bbrc.1993.2449)

Zamir N, Barkan D, Keynan N, Naor Z \& Breitbart H 1995 Atrial natriuretic peptide induces acrosomal exocytosis in bovine spermatozoa. American Journal of Physiology 269 E216-E221.

Zandstra H, Van Montfoort AP \& Dumoulin JC 2015 Does the type of culture medium used influence birthweight of children born after IVF? Human Reproduction 30 530-542. (doi:10.1093/humrep/deu346)

Zhang M, Hong H, Zhou B, Jin S, Wang C, Fu M, Wang S \& Xia G 2006 The expression of atrial natriuretic peptide in the oviduct and its functions in pig spermatozoa. Journal of Endocrinology 189 493-507. (doi:10.1677/joe.1.06483)

Received in final form 30 September 2016

Accepted 11 October 2016
() 2017 Society for Endocrinology Printed in Great Britain 